\title{
NOTES
}

\section{CONSTITUTIONAL LAW: THE SUPREME COURT CONSTRUCTS A LIMITED RIGHT TO TRIAL BY JURY FOR FEDERAL GRIMINAL CONTEMNORS}

In an exercise of the discretionary rule-making authority over the lower federal courts, the Supreme Court in Cheff v. Schnackenburg directed that sentences exceeding six months may not be imposed absent a jury trial or waiver thereof. However, in obliquely withdrawing the previously asserted constitutional basis for the sixmonths limitation, the Court conceivably has undermined the viability of the criminal contemnor"s "right" to a jury trial. Moreover, in light of the potential conflict between the Cheff directive and congressional intent, the aprecise scope and mode of application of the sentencing restriction remains unsettled.

$\mathbf{T}$ HE novel equation of "criminal contempts"1 with "petty offenses"2 advanced in 1964 by the Supreme Court in United States v. Barnett ${ }^{3}$

\footnotetext{
1 While contempts have traditionally been categorized as either civil or criminal, prior to Shillitani v. United States, 384 U.S. 364 (1966), few meaningful judicial de. lineations had been made of the characteristics of either classification. See 20 N.Y.U. INTRA. L. REv. 157, 160-61 (1965). But see Penfield Co. v. SEC, 330 U.S. 585, 595.99 (1947) (Rutledge, J., concurring). The categories have been distinguished on the basis of the beneficiary of the proceeding: a civil proceeding benefits a private litigant by securing for him the fruits of a court order, while criminal proceedings vindicate the court for indignities committed against it. For a statement of and criticism of this categorization, see Nelles, The Summary Power to Punish for Contempt, 31 CouUM. L. Rev. 956, 961 (1931); Schneider, Contempt Powers of the Arixona Courts, 8 Ariz. L. REv. 141, 146 (1966). But see McCrone v. United States, 307 U.S. 61, 64-65 (1939). In Shillitani, the Supreme Court made it clear that contempts, at least in federal courts, are differentiated on the basis of the motivation for the initiation of the particular proceeding: the objective of a criminal contempt is to punish past interferences while the purpose of civil contempt is prospective, that is, to coerce future actions. 384 U.S. at 368-70. See Murphy, The Contempt Power of the Federal Courts, 18 FED. B.J. 34, 35 (1958); 66 CoLUM. L. REv. 182 (1966). Furthermore, it appears that the distinction is more than a mere idle exercise in legal taxonomy since the procedures in criminal contempts differ markedly from those in civil contempts. For example, in criminal proceedings the contempt must be proved beyond a reasonable doubt, while in civil proceedings proof by a preponderance of the evidence is sufficient. Murphy, supra at 35-36. Despite the fact that the civil contemnor can terminate his penalty by compliance with the court order, civil sentences are often indeterminate in length rather than for a fixed period. Id. at 35. See generally GoldFARB, CoNTEMPT OF CourT 49.67 (1963) [hereinafter cited as GoLDFARB]; Cowen, Some Observations on the Law of Criminal Contempt, 7 U. West. AustL. L. REv. I (1965); Fox, The Summary Process to Punish Contempt, 25 L.Q. Rev. 298 (1909); 12 WAYNe L. REv. 699 (1966).

2 See note 49 infra.

8376 U.S. 681 (1964). In Barnett, the defendants, the Governor and Lieutenant
} 
foreshadowed a substantial limitation upon the traditional power of the federal courts to impose criminal sanctions for disobedience of their orders without according jury trials. ${ }^{4}$ In dictum, the Barnett majority asserted that "some members of the Court are of the view that, without regard to the seriousness of the offense, punishment by summary trial without jury would be constitutionally limited to that penalty provided for a petty offense." 5 However, the Court's failure to elucidate clearly the nature and scope of its "petty offense equation" occasioned continued controversy and confusion among courts and commentators. ${ }^{6}$ In the recent case of Cheff $v$. Schnackenburg, ${ }^{7}$ the Supreme Court adopted the substance of the "petty offense equation" to delimit the breadth of the federal courts' discretion over the prosecution and punishment of criminal contemnors. ${ }^{8}$ In so doing, however, the Court's equivocation as to the restriction's conceptual foundation and scope would appear to pose innumerable interpretive dilemmas.

Cheff had been charged with criminal contempt of the Seventh Circuit Court of Appeals for the alleged willful violation of that court's pendente lite order enforcing a cease and desist order issued by the Federal Trade Commission. ${ }^{\circ}$ Relying upon the Barnett

Governor of Mississippi, were brought before tbe Fifth Circuit Court of Apjpeals for disobeying orders issued by that court. They demanded a trial by jury, and the court, being evenly divided on the question as to whether they were so entitled, certified it to the Supreme Court under the authority of 28 U.S.C. $\$ 1254$ (3) (1964). The Supreme Court held that the defendants had neither a constitutional nor a statutory right to a jury trial. The statutory provisions which provide for jury trial in iustances where disobedience to a district court order also constitutes a crime, 18 U.S.C. $\$ \S 402$, 3691 (1964), were held non-applicable since the case involved the order of a court of appeals. 376 U.S. at $690-92$. On the basis of Green v. United States, 356 U.S. 165 (1958), and its own historical survey, the Court found no constitutional rigbt to jury trial. 376 U.S. at 692-700. See notes 38-39 infra and accompanying text. See generally Tefft, United States v. Barnett, "Twas a Famous Victory," 1964 Sup. Cr. REv. 123; The Supreme Court, 1963 Term, 78 HARv. L. REv. 143, 215 (1964); 29 ALBANy L. Rev. 138 (1965); 63 Mrch. L. Rev. 700 (1965); 36 Miss. L. REv. 106 (1964); 25 U. PITT. L. REv. 762 (1964).

See notes 26-39 infra and accompanying text. The federal courts power to punish criminal contemnors without the conferral of a jury trial was limited only by a contrary statutory prescription. See notes 35-37, 65, 95-100 infra and accompanying text.

5376 U.S. at" 695 n.12. See generally notes $49-51$ infra and accompanying text.

- See note 54 infra and accompanying text.

3384 U.S. 373 (1966), 33 BrookLYN L. REv. 120 (1966), The Supreme Court, 1966 Term, 80 HARv. L. REv. 124, 127-29 (1966), 45 TExas L. REv. 176 (1966).

B 384 U.S. at $379-80$.

- The order of Federal Trade Commission against the Holland Furnace Co. and its officers, including President and Chairman of the Board Paul Cheff, prohibited the continuance of unfair methods of competition and deceptive trade practices in the 
dictum, the Seventh Circuit denied defendant's demand for a trial by jury ${ }^{10}$ and proceeded pursuant to the summary contempt procedure required by Federal Rule of Criminal Procedure $42(\mathrm{~b}) .^{11}$ After a full hearing before the court of appeals, the defendant was convicted and sentenced to six months imprisonment. ${ }^{12}$

The Supreme Court, in affirming the conviction, rejected the defendant's contention that criminal contempt proceedings were criminal actions within the ambit of article III ${ }^{13}$ and the sixth amendment, ${ }^{14}$ which guarantee the right to trial by jury. ${ }^{15} \mathrm{Mr}$. Justice Clark, in an opinion joined by three other members of the Court, ${ }^{16}$ reiterated with apparent approval the constitutional demarcation hypothesized in Barnett: the right to a jury trial encompasses only those criminal contempts which fall outside of the "petty offense" category. ${ }^{17}$ Adopting the definition of a "petty

sale of its products. In the Matter of Holland Furnace Co., 55 F.T.C. 55 (1958). The cease and desist order was upheld, both as to the jurisdiction of the FTC to enter it, Holland Furnace Co. v. F.T.C., 269 F.2d 203 (7th Cir. 1959), and on the merits, Holland Furnace Co. v. F.T.C., 295 F.2d 302 (7th Cir. 1961).

${ }^{10}$ In re Holland Furnace Co., 341 F.2d 548, 549 n.1 (7th Cir. 1965).

12 FED. R. CRIM. P. 42 (b): "Disposition Upon Notice and Hearing. A criminal contempt except as provided in subdivision (a) of this rule shall be prosecuted on notice. The notice shall state the time and place of hearing, allowing a reasonable time for the preparation of the defense, and shall state the essential facts constituting the criminal contempt charged and describe it as such. The notice shall be given orally by the judge in open court in the presence of the defendant or, on application of the United States attorney or of an attorney appointed by the court for that purpose, by an order to show cause or an order of arrest. The defendant is entitled to a trial by jury in any case in which an act of Congress so provides. $\mathrm{He}$ is entitled to admission to bail as provided in these rules. If the contempt charged involves dis. respect to or criticism of a judge, that judge is disqualified from presiding at the trial or hearing except with the defendant's consent. Upon a verdict or finding of guilt the court shall enter an order fixing the punishment."

The Notes of the Advisory Committee on the Rules of Criminal Procedure state in paragraph 3 that rule 42 (b) "preserves the right to a trial by jury in those cases in which it is granted by statute, but it does not enlarge the right or extend it to additional cases." Advisory Committee's Note, 4 F.R.D. 405, 430 (1946). Moore states that "while these Notes are not officially sanctioned by the Supreme Court, they are nevertheless persuasive evidence of 'legislative intent' analogous to the notes of Jegislative committees accompanying statutes." 8 MOORE, Federal Practice $\S 1.02$ n.l (1965).

12341 F.2d at 555 .

is U.S. Consr. art. III, § 2: "The Trial of all Crimes, except in Cases of Impeachment, shall be by Jury ...."

14 U.S. Const. amend. 6: "In all criminal prosecutions, the accused shall enjoy the right to a speedy and public trial, by an impartial jury. . . ."

${ }^{25} 384$ U.S. at $378-79$.

${ }^{10} \mathrm{Mr}$. Chief Justice Warren, Mr. Justice Brennan, and Mr. Justice Fortas joined in the prevailing opinion. Mr. Justice Harlan and Mr. Justice Stewart concurred; Mr. Justice Douglas and Mr. Justice Black dissented. Mr. Justice White did not take part in the case.

${ }^{17} 384$ U.S. at 378-79. See also note 5 supra and accompanying text. 
offense" provided by federal statute, ${ }^{18} \mathrm{Mr}$. Justice Clark found that the Seventh Gircuit had not surpassed the prescribed sentence limitation since the penalty imposed in the instant case did not exceed six months imprisonment. ${ }^{19}$ In addition, criminal contempt was deemed not to be intrinsically so serious as to require classification as a "crime." 20 Therefore, since the defendant had no statutory right to a jury trial, ${ }^{21}$ the prevailing opinion concluded that he had been properly tried without a jury. ${ }^{22}$ However, in the exercise of the Court's dual powers to revise contempt sentences and to supervise the administration of justice in the federal courts, the four Justices issued the following directive to provide further guidance for the lower federal courts: "[S]entences exceeding six months for criminal contempt may not be imposed by the federal courts absent a jury trial or waiver thereof." 23 The dissenters, Justices Douglas and Black, posited the theoretical applicability of the "petty offense equation" but found Mr. Justice Clark's six months demarcation standing alone, unsupportable as a constitutional standard. They contended that, since Congress has created no class of "petty" contempts, a proper application of the "petty offense equation" constitutionally requires a jury trial for all federal criminal contemnors. ${ }^{24}$

${ }^{18} 18$ U.S.C. $\$ 1(3)$ (1964): “Any misdemeanor, the penalty for which does not exceed imprisonment for six months or a fine of not more than $\$ 500$, or both, is a petty offense." (Emphasis added.)

10384 U.S. at 380.

20 See ibid.

${ }^{21}$ The defendant had no statutory right to a jury trial since the instant case involved a contempt which neither constituted a crime, see 18 U.S.C. $\$ \$ 402,3691$ (1964), nor arose out of a labor dispute, see 18 U.S.C. $\$ 3692$ (1964), nor arose under civil rights statutes, see Civil Rights Act of 1957, § 151, 71 Stat. 638, 42 U.S.C. § 1995 (1964); Civil Rights Act of 1964, $\$ 1101,78$ Stat. 268, 42 U.S.C. $\$ 2000 \mathrm{~h}$ (1964). See notes $35-37$ infra and accompanying text.

22384 U.S. at 380 .

${ }^{23}$ Ibid. While opinions without majority support are often discounted, Mr. Justice Harlan, in his concurriug opinion, indicated that the directive had the support of six members of the Court: "The decision to extend the right to jury trial to criminal contempt ending in sentences greater than six months is the product of the views of four Justices 'who rest that conclusion on the Court's supervisory power and those of two others who believe that jury trials are constitutionally required in all but "petty" criminal contempts." Id. at 381 .

${ }^{24} I d$. at 391: Assuming congressional prerogative to affect exercises of judicial discretion in contempt proceedings, see notes 93-10I infra and accompanying text, any legislative denomination of particular indirect criminal contempts as "petty" must not exceed the mandates of cases interpreting the sixth amendment right to jury trial. Thus, Congress must consider the gravity of the offense and its indictability at common law. See District of Columbia v. Colts, 282 U.S. 63, 73 (1930). While the prevailing opinion in Cheff posits that the intrinsic seriouness of a criminal contempt does not compel its classification as a "crime," 384 U.S. at 380, indicia exist which sug- 
In contrast, Justices Harlan and Stewart concurred in the judgment but dissented from the directive, asserting that neither the Constitution nor sound public policy dictated the conferral of jury trials for criminal contempt. ${ }^{25}$

The divergent viewpoints proffered in the three Cheff opinions embody the contemporary theories concerning the constitutional status of criminal contempt proceedings. Justices Harlan and Stewart adhered to the classical doctrine that criminal contempts are wholly immunized from the Constitution's jury trial requirements on the theory that contempt is neither a "crime" under article III nor a "criminal prosecution" under the sixth amendment. According to this view, contempt has customarily been denominated an offense sui generis to which the full complement of constitutional safeguards normally attendant criminal prosecutions does not attach. ${ }^{28}$ This unique

gest a contrary conclusion. See note 55 infra. See also 384 U.S. at 391-92 (Douglas, J., dissenting). More troublesome is the deference to be afforded the sanction which potentially could be imposed, for the severity of penalty may render "a statutory offense . . . so serious as to be comparable with common law crimes ...." District of Columbia v. Clawans, 300 U.S. 617, 625 (1937). Assuming that the Cheff six-month demarcation is not constitutionally compelled, see notes 55-56 infra and accompanying text, the precise limits of the maximum penalty which could be imposed upon a petty offense and which would not transgress sixth amendment jury trial requirements has not been specified. The clawans court held that a ninety-day sentence did not present sufficient severity to require the empanelling of a jury. 800 U.S. at 625 . Other cases attempting a delineation of the types of sanctions which distinguish petty offenses from crimes have accepted the six-month delineation set out in 18 U.S.C. § I (3) (1964). See, e.g., United States v. Schiffer, 351 F.2d 91, 96 (6th Cir. 1965); United States v. Au Young, 142 F. Supp. 666, 667 (D. Hawaii 1950). However, unless these courts merely failed to articulate that these limits conform to a delineation which would have been chosen upon an evaluation of constitutional requirements independent of the statute, it is difficult to rationalize how a congressional enactment, originally intended only to do away with "the cumbersome machinery of grand-jury interventions and the finding of bills," 72 CoNG. REc. 9992 (1930) (remarks of Representative Graham), could be deemed a constitutional limitation upon further legislative attempts to punish summarily. The Fifth Circuit, attempting to assign specific limits to the Barnett dictum, has concluded that imposition of a penalty of eighteen months imprisonment probably requires a jury trial. Randazzo v. United States, 339 F.2d 79, 81 (5th Gir. 1964). Thus, the current status of precedent defining the constitutional bounds within which offenses may be dealt with summarily places the maximum duration of imprisonment at some point between six and eighteen months.

25384 U.S. at $381-83$.

${ }^{20}$ The term "sui generis" is conclusionary; yet the courts have consistently failed to give further elaboration. In Mjers v. United States, 264 U.S. 95 (1924), the Court observed that "while contempt may be an offense against the law and subject to appropriate punishment," since the beginning of our government "proceedings to punish such offenses lave been regarded as sui generis, and not "criminal prosecutions' within the Sixth Amendment or common understanding." Id. at 104-05. (Italics in original.) However, another court stated that it saw "no advantage in rehashing the discussions on whether criminal contempt is sui generis, offense, crime, or felony. Criminal contempts are criminal contempts; some of the procedural and substantive 
isolation from the normal requisites of procedural due process has been rationalized on the grounds that the courts' power to punish summarily for contempt was well established at common law ${ }^{27}$ and is indispensible to the proper functioning of the judicial system. ${ }^{28}$

However, the federal courts' abuse of the unbridled procedural discretion sanctioned by the traditional theory has resulted in gradual mitigation of its pristine absolutism. ${ }^{29}$ Initially, the courts, and subsequently Congress, deemed the appropriateness of summary procedures dependent upon a classification of the contempt as "direct" or "indirect," the latter occurring outside of the presence of the court and generally consisting of a violation of a court order. ${ }^{30}$ While the

law applied to criminal contempts is as though they were crimes, and some of it is not." Warring v. Huff, 122 F.2d 641 (D.C. Cir.), cert. denied, 314 U.S. 678 (1941). See Penfield Co. v. S.E.C., 330 U.S. 585, 609 (1947); Blackmer v. United States, 284 U.S. 421, 440 (1932); United States v. Goldman, 277 U.S. 229 (1928); Ex parte Grossman, 267 U.S. 87, 117-18 (1925); Michaelson v. United States, 266 U.S. 242 (1914); Gompers v. United States, 233 U.S. 604 (1914); Bessette v. W. B. Conkey Co., 194 U.S. 324, 336-37 (1904); O'Neal v. United States, 190 U.S. 36, 38 (1903); Creekmore v. United States, 237 Fed. 743 (8th Cir. 1916); Merchants' Stock \& Grain Co. v. Board of Trade, 201 Fed. 20 (8th Cir. 1912).

One commentator sees the classification of criminal contempts as sui generis as merely expressing the conclusion that contempt procedures are indispensable to the proper functioning of the judicial branch and states that the label does not contribute to a solution of the problems presented by the unique proceedings. See Lane, The Contempt Power v. the Concept of a Fair Trial, 50 KY. L.J. 351, 353 (1962).

Some courts have not used the sui generis label but merely lield contempts not to be "crimes." See, e.g., Ex parte Burr, 4 Fed. Cas. 791, 797 (No. 2186) (C.C.D.C. 1823). See also United States v. Bamett, 376 U.S. 681 (1964); Green v. United States, 356 U.S. 165 (1958).

${ }^{27}$ See, e.g., Green v. United States, supra note 26, at 185-86; United States v. Barnett, supra note 26, at 692-93. But see notes $41-42$ infra and accompanying text.

${ }_{28}$ "It lias always been one of the attributes-one of the powers necessarily incident to a court of justice-that it should have this power of vindicating its dignity, of enforcing its orders, of protecting itself from insult, without the necessity of calling upon a jury to assist it in the exercise of this power." Eilenbecker v. District Court, 134 U.S. 31, 36 (1890). See, e.g., Marshall v. Gordon, 243 U.S. 521, 541-43 (19i7); Bessette v. W. B. Conkey Co., 194 U.S. 324, 327, 333 (1904); Ex parte Terry, 128 U.S. 289, 30810 (1888); Ex parte Fisk, 113 U.S. 713, 718 (1885); Anderson v. Dunn, 19 U.S. (6 Wheat.) 204, 228-29 (1821); United States v. Hudson, 11 U.S. (7 Cranch) 32, 34 (1812). Other important benefits which accrue to the administration of justice through the summary punishment power include speed of prosecution and punishment, increased deterrence of contemptuous conduct, avoidance of delays, and promotion of the dignity of the court. Some commentators have argued that these advantages would be impaired if courts were forced to rely on prosecutions by the district attorney in a separate proceeding. See generally Cowen, supra note 1, at 7; 39 So. CAL. L. REv. 463, 467 (1966); 27 U. PitT. L. Rev. 723, 725 (1966); 65 YALE L.J. 846, 855 (1956).

${ }^{20}$ See Green v. United States, 356 U.S. 165,196 n.5 (1958) (Black, J., dissenting); 25 U. PrTt. L. REv. 762, 764 (1964). Cf. Comment, 58 Mich. L. Rev. 258, 264-66 (1958).

${ }^{30}$ See Ex parte Terry, 128 U.S. 289, 307-09 (1888); GoldFarB 68-69; Lane, supra note 26, at 353-54; Wright, Byrne, Haakh, Westbrook \&. Wheat, Civil and Criminal Con- 
procedural requisites for the punishment of direct contempts have remained relatively unregulated, ${ }^{31}$ the history of indirect contempt evinces an increasing propensity on the part of both the courts and Congress to resolve conflicts between the "demands" of judicial efficiency and due process to the contemnor in favor of the latter. ${ }^{32}$ At a minimum, federal rule 42 (b) requires reasonable notice and a hearing for all indirect contempts. ${ }^{33}$ Furthermore, the courts have gradually accorded nearly the full panoply of procedural safeguards except the right to trial by grand and petit juries. ${ }^{34}$ Finally, a statu-

tempt in the Federal Courts, 17 F.R.D. 167, 170 (1955). Conversely, a direct contempt has traditionally encompassed indignities and interferences of which a court could take empirical notice. The symetry of the direct-indirect dichotomy, however, has been somewhat blurred by Harris v. United States, 382 U.S. 162 (1965).

s2 "A criminal contempt may be punished summarily if the judge certifies that he saw or heard the conduct constituting the contempt and that it was committed in the actual presence of the court. The order of contempt shall recite the facts and shall be signed by the judge and entered of record." FED. R. CRIM. P. 42 (a). The only procedural limitation in this solitary statutory provision covering direct contempt lies in the form of narrow definition of the substantive scope of direct contempt. In Harris v. United States, supra note 30, the Court held that the application of rule 42 (a) was limited to situations where immediate judicial action is needed to rectify contemptuous conduct, such as threatening the judge with physical harm or seriously obstructing the court's proceedings, and that a refusal to testify was not such a situation. 382 U.S. at 164-65. See Lane, supra note 26, at 376-94; Luther, Recent Trends Curtailing the Summary Contempt Power in the Federal Courts, 8 HAstINGs L.J. 56 (1956); 51 CORNELL L.Q. 815 (1966); 70 Dick. L. REv. 254 (1966); 1966 DUKE L.J. 814; 39 Temp. L.Q. 368 (1966); 27 U. PitT. L. Rev. 723 (1966); 12 Wayne L. Rev. 699 (1966).

${ }^{32}$ See Goldfarb 75-77.

${ }^{88}$ See note 11 supra.

8t Procedural protections granted to contemnors include the following: (1) Im. munity from double jeopardy. In re Bradley, 318 U.S. 50, 52 (1943). (2) Protection against self-incrimination. See Michaelson v. United States, 266 U.S. 42, 66 (1924); Gompers v. Buck's Stove \&: Range Co., 221 U.S. 418, 447-48 (1911). But see Merchants' Stock \& Grain Co. v. Board of Trade, 201 Fed. 20, 27-29 (8th Cir. 1912).

(3) Compulsory process to obtain witnesses in his favor. Sce Blackmer v. United States, 284 U.S. 421, 442 (1932). (4) The requirement of proof beyond a reasonable doubt. See, e.g., Welling v. United States, 9 F.2d 292, 293 (6th Cir. 1925); Stewart v. United States, 236 Fed. 838, 843 (8th Cir. 1916); Schwartz v. United States, 217 Fed. 866, 870 (4th Cir. 1914). (5) Eligibility for executive pardon. Ex parte Grossman, 267 U.S. 87, $118-22$ (1925). (6) Protection of statutes of limitations. Pendergast v. United States, 317 U.S. 412, 417-21 (1943). (7) The criminal presumption of innocence. Michaelson v. United States, supra at 66; Gompers v. Buck's Stove \& Range Co., supra at 444. (8) The right to an unbiased judge. Ungar v. Sarafite, 376 U.S. 575, 583 (1964); Offutt v. United States, 348 U.S. 11, 17-18 (1954); Cooke v. United States, 267 U.S. 517, 539 (1925). (9) The right to a public trial. In re Oliver, 333 U.S. 257, 266.73 (1948). (10) The right not to be denied free speech. Wood v. Georgia, 370 U.S. 375, 394.95 (1962); Craig v. Harney, 331 U.S. 367, 373 (1947); Pennekamp v. Florida, 328 U.S. 331, 346-50 (1946); Bridges v. California, 314 U.S. 252, 270-78 (1941). (11) The right to vigorous argument of counsel. Holt v. Virginia, 381 U.S. 131, 186.38 (1965). (12) The right to appeal. Green v. United States, 356 U.S. 165, 188 (1958); Harris v. United States, 382 U.S. 162, 171 \& n.13 (1965) (dissent). (13) The right to petition for habeas corpus. Savin, Petitioner, 131 U.S. 267 (1889). 
tory right to trial by jury has been conferred where the act of contempt also constitutes a separate crime, ${ }^{35}$ occurs in connection with a labor dispute, ${ }^{36}$ or arises under certain civil rights statutes. ${ }^{37}$ Nevertheless, despite the aforesaid liberalizing trends, the Supreme Court, as recently as 1958, in Green $v$. United States, ${ }^{38}$ re-emphasized the continued viability of the absolute exemption of criminal contempt from the jury trial requirements of article III and the sixth amendment. $^{39}$

A second contemporary theory is represented by the position of Justices Douglas and Black that criminal contempt is within the ambit of the Constitution's guaranty of the right to trial by jury. Adherents of this viewpoint in recent years have levelled a vigorous attack upon the sui generis status of criminal contempts. ${ }^{40}$ In the first instance, the historical foundation for the courts' summary porver over contempts is deemed to be of questionable validity. It

${ }^{85}$ See 18 U.S.C. $\$ \S 402,3691$ (1964). Specifically exempted from the purview of these sections are "contempts committed in the presence of the court." The application of these sections, originally enacted under the Clayton Act, was held not limited to antitrust proceedings in Sandefur v. Canoe Creek Coal Co., 293 Fed. 379 (6th Cir. 1923), certified question answered, 266 U.S. 42 (1924). See generally Frankfurter \& Landis, Power of Congress over Procedure in Criminal Contempts in "Inferior" Federal Gourts $\rightarrow$ A Study in Separation of Powers, 37 HARv. L. REv. 1010, 1038-42, 1052-58 (1924).

${ }^{80}$ See 18 U.S.C. $\$ 3692$ (1964). As in the case of contemptuous actions which also constitute crimes, the guarantees of this section do not extend to direct contempts.

${ }^{87}$ Civil Rights Act of 1957, $\$ 151,71$ Stat. 638, 42 U.S.C. $\$ 1995$ (1964); Civil Rights Act of 1964, $\S 1101,78$ Stat. 268,42 U.S.C. $\$ 2000 \mathrm{~h}$ (1964). In cases where the sanction imposed does not exceed a fine of 300 dollars or imprisonment in excess of forty-five days, the 1957 statute gives a judge discretion to try the contemnor without a jury. ${ }^{3} 356$ U.S. 165 (1958).

so The defendants in Green were convicted of a violation of the Smith Act and released on bail while the case was on appeal. When the conviction was affirmed, the district court signed an order for the surrender of the defendants. For disobedience of this order the defendants were convicted of criminal contempt and sentenced to an additional three years imprisonment. In holding that the defendants were properly convicted without a jury trial, the Supreme Court, without extended discussion, relied only on past precedent: "The statements of this Court in a long and unbroken line of decisions ranging from misbehavior in court to disobedience of court orders establish beyond peradventure that criminal contempts are not subject to jury trial as a matter of constitutional right." Id. at '183. See generally 25 BROOKLYN L. REv. 118 (1958); The Supreme Court, 1957 Term, 72 HARv. L. REv. 77, 156 (1958); 36 U. DET. L.J. 180 (1958).

10 See GoldFarb 180-84. The attack upon criminal contempt procedures has increased in recent years. See Sacher v. United States, 343 U.S. 1, 20-23 (1952) (Black, J., dissenting); Fisher v. Pace, 396 U.S. 155, 167-68 (1949) (Murphy, J., dissenting); Ballantyne v. United States, 237 F.2d 657, 667-68 (5th Cir. 1956) (Cameron, J., concurring in part, dissenting in part); Farese v. United States, 209 F.2d 312, 315 (1st Cir. 1954). Hostility towards the summary punishment of criminal contempts has existed to a lesser degree throughout the years, see, e.g., 1 Livingston, Complete WORks on Criminal JURISPRUdenCE 258-67 (1873). 
is contended that modern scholarship not only has unearthed no evidence to support the assertion that the drafters of the Consti. tution had differentiated between "contempts" and "crimes,"41 but also that it has eviscerated the assumption that summary pro. cedures were employed under the common law.42 Furthermore, be. cause of the frequent use of contempt proceedings ${ }^{43}$ and the harsh.

${ }^{2}$ See Goldfarb 180; Kaye, Petty Offendets Have No Peets, 26 U. CuI. L. Rav. 245, 261-65 (1959). But see Tefft, supra note 3, at 128-29.

2 Among the most prominent writings examining the historical background of the contempt power are those of Sir John Fox: THE History of ConTEMPT of CourT (1927); The Writ of Attachment, 40 L.Q. REv. 43 (1924); The Practice in Contempt of Court Cases, 38 L.Q. REv. 185 (1922); The Nature of Contempt of Court, 37 L.Q. REv. 191 (1921); Eccentricities of the Law of Contempt of Court, 36 L.Q. REv. 594 (1920); The Summary Process to Punish Contempt, 25 L.Q. REv. 238 (1909); The King v. Almon (pts. I-1I), 24 L.Q. REv. 184, 266 (1908). See Comment, 57 MICH. L. REv. 258, 260 (1958): "Fox summed up the procedure to punish indirect contempts as having been unknown originally at common law, created by the Star Chamber, and later filtered into common law courts after abolition of the Star Chamber in 1641." This history was hidden from both American and English courts due to the inaccuracy of Justice Wilmot's unreported but well-known opinion in Rex v. Almon. See Frankfurter \& Landis, supra note 35, at 1046-50; Goldfarb \& Kurzman, Civil Rights v. Civil Liberties: The Jury Trial Issue, 12 U.C.L.A.L. REv. 486, 488-89 (1965); Comment, 10 KAN. L. REv. 433-34 (1962). See generally GOLDFARB 13-20; 2 HOLDSWORTH, A HISTORY of English Law 391-94 (3d ed. 1927); Thomas, Problems of Contempt of Court 8-9 (1934).

4. An expansion in the apphications of the contempt device is largely responsible for its increased use. For example, federal agencies have no power to punish disobedience of their orders. See ICC v. Brimson, 154 U.S. 447 (1894); GoldFarB 128:29. They must therefore seek enforcement through the court contempt proceedings provided by various provisions. See, e.g., Perishable Agricultural Commodities Act of 1930, $\$ 12$ (c), 46 Stat. 536, 7 U.S.C. $\$ 499 \mathrm{~m}$ (c) (1964) (Dep't of Agriculture); Federal Seed Act $\$ \S 410-11$, 53 Stat. 1287 (1939), 7 U.S.C. $\$ \S 1601-02$ (1964) (same); Clayton Act $\$ 11,38$ Stat. 734 (1914), as amended, 15 U.S.C. $\$ 21$ (1964) (enforcement of FTC, ICC, CAB, and Federal Reserve Board orders concerning monopolies and combinations); Federal Trade Comm'n Act $\$ 5$ (c), 52 Stat. 112 (1938), as amended, 15 U.S.C. $\$ 45$ (c) (1964) (FTC orders dealing with unfair methods of competition and deceptive trade practices); Securities Exchange Act $\$ 21$ (c), 48 Stat. 900 (1934), 15 U.S.C. §78u (c) (1964) (SEG); Public Utility Holding Company Act $\$ 18$ (d), 49 Stat. 831 , 15 U.S.C. $\$ 79$ (d) (1964) (same); Small Business Investment Act $\$ 309(\mathrm{f})$, added by 75 Stat. 755 (1961), 15 U.S.C. $\$ 687 \mathrm{a}(\mathrm{f}$ (1964) (Small Business Administration); Tariff Act of 1930, $\$ 333$ (b), 46 Stat. 699, as amended, 19 U.S.C. $\$ 1333$ (b) (1964) (Tariff Commission); National Labor Relations Act $\$ \$ 10(\mathrm{e}), 11(2), 61$ Stat. 147 (1947), as amended, 29 U.S.C. $\$ \$ 160$ (e), 161 (2) (1964) (NLRB); Atomic Energy Act of 1954, \$231, 68 Stat. 960, 42 U.S.C. $\$ 2281$ (1964) (Att'y General); Railroad Uncmployment Insurance Act $\$ 12$ (b), 52 Stat. 1107 (1938), as amended, 45 U.S.C. $\$ 362$ (b) (1964) (Railroad Retirement Bd.); Communications Act of 1934, $\$ 409$ (d), as amended, 47 U.S.C. $\$ 409$ (g) (1964) (FCC); Interstate Commerce Act $\$ 12,24$ Stat. 383 (1887), as amended, 49 U.S.C. $\$ 12$ (3) (1964) (ICC). See also notes 81,89 infra and accompany text. While some of the enforcement provisions do not expressly provide for contempt proceedings, the contempt power is indirectly authorized by provisions for enforcement through the courts. See, e.g., H.R. REP. No. 1371, 74th Cong., Ist Sess. 5 (1935). See generally, Jaffe, The Judicial Enforcement of Administrative Orders, 76 HARv. L. REV. 865 (1963). 
ness of the penalties imposed therein, ${ }^{44}$ it is argued that summary criminal punishment is incompatible with modern concepts of criminal justice, notwithstanding any contrary historical justifications. The burgeoning acceptance of this defendant-oriented theory culminated in Green, wherein Mr. Justice Black, speaking for three members of the four-vote minority, ${ }^{45}$ concluded that the judicial precedent upon which the traditional doctrine was based was "wrong -wholly wrong." 46

The doctrine subsequently temporized in the Barnett dictum represented an intermediate theory. Although the dictum intimated, for the first time, that a majority of the Justices was prepared to repudiate the traditional doctrine, ${ }^{47}$ the Court held that a trial by jury was not constitutionally required for all indirect contempts. ${ }^{48}$ Rather, the Barnett Court appeared to rely upon Mr. Justice Goldberg's assertion in dissent that criminal contempts "were tried without a jury at the time of the Constitution ... because they were deemed a species of petty offenses punishable by trivial penalties"49

\footnotetext{
"Cases imposing severe sentences include the following: Piemonte v. United States, 367 U.S. 556 (1961) (eighteen months); Reina v. United States, 364 U.S. 507 (1960) (two years); Brown v. United States, 359 U.S. 41 (1959) (fifteen months); Green v. United States, 356 U.S. 165 (1958) (three years); Nilva v. United States, 352 U.S. 385 (1957) (one year and one day); Savin, Petitioner, 131 U.S. 267 (1889) (one year); Collins v. United States, 269 F.2d 745 (9th Cir. 1959) (three years); United States v. Thompson, 214 F.2d 545 (2d Cir.) (per curiam), cert. denied, 348 U.S. 841 (1954) (four years). See generally Cheff v. Schnackenberg, 384 U.S. 373, $384-85$ (1966) (Douglas, J., dissenting); United States v. Barnett, 376 U.S. 681, 751 (1964) (Goldberg, J., dissenting); Green v. United States, 356 U.S. 165, 208 (1958) (Black, J., dissenting).

¿5 Mr. Chief Justice Warren and Mr. Justice Douglas concurred in Mr. Justice Black's dissent. Mr. Justice Brennan dissented in a separate opinion.

t6 356 U.S. at 195 (Black, J., dissenting).

¿T See Tefft, supra note 3, at 123.

${ }^{8} 376$ U.S. at $692-700$.

เ 376 U.S. at 751-52 (Goldberg, J., dissenting). The exemption from constitutional jury trial requirements for minor offenses, referred to as the "petty offense exception," originated in Gallan v. Wilson, 127 U.S. 540 (1888). There the Court reasoned that article $3, \S 2$ of the Constitution was to be "interpreted in the light of the principles which, at common law, determined whether the accused, in a given class of cases, was entitled to be tried by a jury." Id. at 549. The Court concluded that "except in that class or grade of offenses called petty offenses, which according to the common law, may be proceeded against summarily," the defendant must be afforded trial by jury. Id. at 557. The distinction, which was supported in its historical foundation in Frankfurter \& Corcoran, Petty Federal Offenders and the Constitutional Guaranty of Trial by Jury, 39 HARv. L. REv. 917 (1926), was elaborated upon in District of Columbia v. Colts, 282 U.S. 63 (1930), and District of Columbia v. Clawans, 300 U.S. 617 (1937). However, a recent commentator has issued a strong challenge to the theory. Kaye, Petty Offenders Have No Peers, 26 U. CHI. L. Rev. 245 (1959). Kaye contends that the petty offense distinction "reflects an undesirable technique of
} 
and his observation that the federal courts' historical use of summary procedures for criminal contempts was generally accompanied by the imposition of lenient punishments. ${ }^{50}$ As a necessary concomitant, moreover, Barnett inferred that where criminal contempts were punishable by penalties more severe than those imposed for petty offenses a jury trial was required by article III and the sixth amendment. ${ }^{.1}$

However, the Barnett Court's oblique construction of the intermediate theory merely intensified the controversy as to when a jury trial is required for criminal contempts. On the one hand, the traditionalists, assailing Justice Goldberg's reinterpretation of history, rejected the asserted applicability of the "petty offense equation."52 On the other hand, others argued that the Court had misapplied the "equation" by looking solely to the severity of the punishment actually imposed rather than the maximum permissible punishment. ${ }^{53}$ Moreover, the indefiniteness of the dictum itself resulted in immediate juridical conflict as to its precise requisites, particularly as to the proper line of demarcation for "petty" sentences. 54

Constitutional interpretation and amounts to an unwarranted abrogation by the federal government of a Constitutional right," and that the argument supporting it is supported neither by history nor logic. Id. at 245-46. In addition, the Clawans case is seen as a "departure from all reason, policy, and precedent." Id. at 277.

50376 U.S. at 751.

61 "If a criminal contempt (or any other violation of law) is punishable only by a trivial penalty, then the Constitution does not require trial by jury. If a violation of law is punishable by a nontrivial penalty, then the Constitution does require trial by jury whether the violation is labeled crimiual contempt or anything else." Id. at 756-57 (Goldberg, J., dissenting).

62 See Tefft, supra note 3 , at $130-31$. The challenge is made primarily against the contention that the courts are powerless to impose any but trivial penalties for criminal contempts. Nothing in the constitutional convention debates is seen to indicate that such a limit is constitutionally imposed. Ex parte Burr, 4 Fed. Cas. 791 (No. 2186) (C.C.D.C. 1823), in holding the power to summarily punish contempt in the fudiciary Act of 1789 constitutional, stated that since many of the members of the convention were members of the first Congress, "it cannot be believed that they would" have silently acquiesced in so palpable a violation of the then recent constitution ...." Id. at 797. Judge Learned Hand, in the Second Circuit opinion in Green, stated that "There is no reason to suppose, because courts had not up to 1914 imposed imprison. ment for more than a year, that they thought that they had not the power to do so." United States v. Green, 241 F.2d 631, 634 (1957), aff'd, 356 U.S. 165 (1958). See Grossman v. United States, 1 F.2d 941 (N.D. Ill. 1924), aff'd, 280 Fed. 683 (7th Cir. 1922); Ex parte Grossman, 267 U.S. 85 (1925) (one-year sentence and a 1,000 dollar fine held not to conflict with article III and the sixth amendment); In re Gompers, 40 App. Cas. 293 (App. D.C. 1913). Compare Frankfurter \& Corcoran, supra note 49 with Kaye, supra note 49.

${ }^{53}$ See Note, 29 A1.baNY L. Rev. 138, 141-42 (1965); .'ote, 63 Mich. L. Rrv. 700, 703. 04 (1965).

s The lower courts, in attempting to appl; the Barnelt dictum, drew varying lines 
Against this background of controversy and confusion, Mr. Justice Clark's directive in Cheff adhered to Barnett's intermediate position that the federal courts must either provide jury trials or limit sentences to six months imprisonment. ${ }^{55}$ However, in con-

of demarcation. In Randazzo v. United States, 339 F.2d 79 (5th Cir. 1964), where an eighteen-month sentence was vacated, the court indicated its uncertainty by stating that "respectful consideration of that dictum calls for the exercise of judgment or discretion by the district court as to whether to honor the defendant's demand for a jury trial, or to impose the same or a lesser sentence upon the defendant if he is again found guilty." Id. at 81. One year later, the same court was still in doubt: "The Court will undoubtedly assess the effect of the Supreme Court's caveat-dictum in footnote 12 of the Barnett case with regard to the imposition of a penalty as severe as three years imprisonment without a jury trial." Johnson v. United States, 314 F.2d 401, 411 n.21 (5th Cir. 1965). The Second Circuit, in United States v. Bialkin, 331 F.2d 956, 959 (2d Cir. 1964), while avoiding the ultimate issue because the defendant had pleaded guilty at trial, seemed to approve of the defendant's contention that the dictum imposed a six-month limit on non-jury sentences. The District of Columbia Circuit revealed the proposition, perhaps valid even after Cheff, that if local code provisions are even more restrictive as to the penalty imposable for petty offenses than the federal code, the local code may be the relevant standard: "Accordingly we think it proper to instruct the District Court that if on remand it proceeds without a jury, it can impose no greater imprisonment than ninety days [the maximum sentence without jury trial in the District of Columbia is ninety days, D.C. CoDE $\$ 11-715 a$ (1961)]." Rollerson v. United States, 343 F.2d 269, 278 (D.C. Cir. 1964). See 63 Mrch. L. Rev. $700,703.04 \&$ n.23 (1965). Without apparent substantiation Tefft constructs the equation using the six-month figure of 18 U.S.C. $\$ 1$ (3) (1964). Tefft, United States $v$. Barnett, "Twas a Famous Victory," 1964 SUP. CT. REv. 123, 136.

Another controversy resultant from the obscurity of the Barnett dictum was its potential application to direct contempts. If jury trials were constitutionally compelled where sentences exceeded those imposed for petty offenses, procedures for all contempts, irrespective of their classification within the direct-indirect dichotomy, would come within the purview of this mandate. Yet, despite the breadth given the constitutional standard in Barnett, most courts restricted the application of the dicturn to indirect contempts. For example, the Second Circuit, in considering the right to jury trial, held the dictum inapplicable because "Harris' contempt was committed in the presence of the court and the contempt proceeding was undertaken prior to compliance with the court's order, in both of which respects this case differs from Barnett ...." United States v. Harris, 334 F.2d 460, 463 (2d Cir. 1964), rev'd on other grounds, 382 U.S. 162 (1965). (Italics added.) See also United States v. Tramunti, 343 F.2d 548, 551-52 (2d Cir. 1965); United States v. Castaldi, 338 F.2d 883, 885 (2d Cir. 1964), revod on other grounds, 384 U.S. 886 (1966); United States v. Shillitani, 345 F.2d 290, 294 (2d Cir. 1965), rev'd on other grounds, 384 U.S. 364 (1966).

In one case, however, the dictum was followed even though a direct contempt was involved. In Rollerson v. United States, 343 F.2d 269 (D.C. Cir. 1964), the defendant threw a water pitcher at the prosecutor during the former's robbery trial. The court's expansive interpretation of the dictum is minimized by the fact that a defense of insanity was being asserted by the defendant during the proceeding, and thus the court of appeals may have felt that the defendant was entitled to have a jury decide his responsibility for the act. Id. at 276-77; see $63 \mathrm{MrcH}$. L. REv. 700, $706 \mathrm{n} .40$ (1965).

${ }^{55}$ See note 19 supra and accompanying text. The apparent clarification given the Barnett "penalty-imposed" criteria by the Cheff "six-months-or-jury-trial" delineation merely perpetuates the perfunctory assumption of the Barnett court that petty offenses are distinguished from crimes solely on the basis of the severity of the penalty imposed. 
While Mr. Justice Clark's opinion at least intimates a recognition of the standards for delineation traditionally considered, 384 U.S. at 379.80 , and, thus, appears more in. lightened than the Barnett dictum in which consideration of the severity of the offense was specifically discounted, see text accompanying note 5 supra, the prevailing view in Cheff failed to give full effect to factors which might compel classification of criminal contempts as crimes rather than petty offenses. The criteria for differentiation have never been precisely designated. See Smith v. United States, 128 F.2d 990, 991 (5th Cir. 19342); Frankfurter \& Corcoran, suprà note 49, at 980-82; Kaye, supra note 49, at 271-73; Stewart, The Right to Trial by Jury in Criminal Prosecutions for Petty Federal Offenses, 39 W. VA. L.Q. 40, 46.47 (1992). The Supreme Court has said, however, that the distinction between the categories "depends primarily upon the nature of the offense." District of Columbia v. Colts, 282 U.S. 63, 73 (1930). See, e.g., Natal v. Louisiana, 139 U.S. 621, 624 (1891); Callan v. Wilson, 127 U.S. 540, 555-56 (1888). See generally Stewart, supra; Comment, 40 YALE L.J. 1303 (1931). The elucidation of this classification has utilized several criteria, the application of which to indirect criminal contempts iudicates the argnably serious nature of these offenses. See Cheff v. Schnackenburg, 384 U.S. 373, 390 (1966) (Douglas, J., dissenting). In the first instance, under the early common law, indirect contempts were indictable offenses. See Goldfarb 14-15; Fox, The Nature of Contempt of Court, 37 L.Q. Rev. 191 (1921); Fox, Eccentricities of the Law of Contempt of Court, 36 L.Q. Rev. 394, 396-97 (1920); Fox, The Summary Process to Punish Contempt, 25 L.Q. REv. 238, 244-48 (1909); Fox, The King v. Almon (pt. II), 24 L.Q. REv. 266-70 (1908); Frankfurter \& Landis, supra note 35, at 1042, 1046. Secondly, since contempt "wends historically back to the early days of England and the crown," GoLdfark 9, the offense would seem to be malum in se-or offensive to principles of natural, moral, or public law-rather than mere malum prohibitum-or unlawful solely because of statutory proscription, Riss \& $\mathrm{Co}$. v. United States, 262 F.2d 245, 248 \& n.2 (8th Cir. 1958). Finally, as a consequence of his conviction, the contemnor may be made to endure certain civil disabilities such as classification as a convict, Creekmore v. United States, 297 Fed. 743 (8th Cir. 1916), cert. denied, 242 U.S. 646 (1917), or exclusion from burial in Arlington National Cemetery, see Cheff v. Schnackenburg, 384 U.S. 373, $385-86$ (1966) (Douglas, J., dissenting). See also GoldFarb 178.

Furthermore, even if the "petty" nature of criminal contempts wère posited, Mr. Justice Clark's identification in Cheff of a "petty offense" based solely upon the penalty imposed is made without regard to the usual constitutional standards. As Mr. Justice Douglas noted, 384 U.S. at 387-91, for purposes of constitutional categorization of offenses, it is the "maximum potential sentence," not the "penalty actually imposed," which has been determinative. See, e.g., Giammario v. Hurney, 311 F.2d 285, 287 (3d Cir. 1962); Barde v. United States, 224 F.2d 959 (6th Cir. 1955); Creekmore v. United States, supra. Yet, if the Cheff directive merely reflects a policy decision, the deviation from the constitutional standards is immaterial since this type of resolution, while possibly giving deference to the constitutional criteria, would not be determined by a singular factor.

That Cheff represents a balancing of competing interests and not a strict adherence to a specific standard is suggested by the fact that a literal application of the constitutional criterion could result in an unnecessary interference with the effective functioning of the federal courts. Since there is no statutory limitation upon penalties for most contempts, see 18 U.S.C. $\$ \S 401-02$ (1964), application of the "maximum potential sentence" standard would necessitate jury trials upon every occurrence of this offense. See Cheff v. Schnackenburg, 384 U.S. 373, 391-93 (1966) (Douglas, J., dissenting). Conceivably, the Cheff court may have concluded that adequate protection of an in. dividual contemnor did not necessitate possibly burdensome jury trials for minor affronts to the judicial mandate.

Nevertheless, the use of the "penalty-imposed" standard in the Cheff directive seems 
tradistinction to the asserted constitutional mandate for this restriction proffered in Barnett, Mr. Justice Clark relied solely upon the Supreme Court's policy-making authority over the lower federal courts. ${ }^{56}$ Nevertheless, it is arguable that the Cheff directive may be constitutionally compelled. Under such an interpretation, the Court's rejection of a right to a jury trial in the instant case would merely constitute a reaffirmation of Barnett's constitutional demarcation. ${ }^{57}$ Mr. Justice Clark's reliance upon nonconstitutional grounds for the directive might be explained simply as a manifestation of the Court's traditional hesitation prematurely to render a constitutional decision. ${ }^{58}$

ultimately a questionable policy decision especially as to indirect contempts since a judge must decide whether to impanel a jury before any evidence is presented as to such matters as the precise nature of the contempt and possible mitigating circumstances. Thus, an accurate prediction cannot realistically be anticipated. As formerly argued to the Supreme Court, to endorse this pre-trial prediction is "to distribute a constitutional right according to blind chance-the defendant whose judge underestimates the likely sentence will be deprived of a jury; the defendant whose judge overguesses may be given a jury without being entitled to one." Brief for the United States, p. 64, Harris v. United States, 382 U.S. 162 (1965).

so 384 U.S. at 380 . See note 62 infra and accompanying text.

${ }^{87}$ The Court's intent to accept the constitutional basis of the Barnett dictum is suggested by several aspects of the Cheff opinion. For example, reference is made to the Barnett dictum with no indication of disapproval. Also, if Barnett had not created a constitutional right to trial by jury, the Cheff Court need not have undertaken its lengthy discussion of whether the petitioner had been denied a right to have his case considered by a jury; a mere statement as to the nonexistence of such a right would have provided a sufficient disposition of the petitioner's contention. Moreover, the Barnett proposition that summary punishment is "constitutionally limited to that penalty provided for petty offenses," 376 U.S. at 695 n.12 (dictum), necessarily implies that trial by jury is constitutionally compelled where the sentence exceeds "petty" punishment. The Cheff Court arguably recoguized this concomitant of the Barnett dictum when it asserted that the petitioner was demanding too broad an interpretation of the prior case when he contended that on the basis of article III and the sixth amendment, "the right to jury trial attaches in all criminal contempts and not merely in those which are outside the category of 'petty offenses.' " 384 U.S. at 378-79. (Emphasis added.) In other words, the analysis of the Cheff Court leaves the inference that the relevance of the Barnett dictum may have been conceded had the mandate presented there been argued in accordance with the original demarcation. Finally, the language of the Court does not contradict a contention that the only result intended was a rejection of the petitioner's attempt to add breadth to the Barnett holding. It could also be said that the Court presented the "six-months-sentence" criteria in order to add specificity to the Barnett delineation and thereby to anticipate similar arguments by future petitioners.

${ }^{88}$ See Ashwander v. TVA, 297 U.S. 288, $346-47$ (1936) (Brandeis, J., concurring). See also Poe v. Ullman, 367 U.S. 497, 503 (1961); Clay v. Sun Ins. Office Ltd., 363 U.S. 207, 211-12 (1960); United States v. UAW, 352 U.S. 567, 590-93 (1957); Rice v. Sioux City Mem. Park Cemetery Inc., 349 U.S. 70, 74 (1955); United States v. Hayman, 342 U.S. 205, 223 (1952); Rescue Army v. Municipal Court, 331 U.S. 549, 568-69 (1947). 
On the other hand, the aforesaid rationalization for the directive's policy foundation seems tenuous, at best, for little justification exists for any reluctance to reach the constitutional question in light of Barnett's previous assertion of a constitutional interpretation. Moreover, the directive itself would thereby be rendered superfluous, for the discretionary power supporting it would have been exercised unnecessarily. Finally, the prevailing opinion appeared simply to employ the "petty offense equation" as an analogy for analytic purposes. That is to say, criminal contempts were viewed as only "equivalent to" petty offenses ${ }^{59}$ and their sui generis nature was re-emphasized. ${ }^{60}$ The more persuasive interpretation, therefore, would seem to be that Mr. Justice Clark has obliquely withdrawn the constitutional basis of the Barnett-Cheff restriction. ${ }^{61}$

However, the prevailing opinion's sole reliance upon the Court's revisory and supervisory powers as support for its restriction poses serious questions as to the judiciousness and potential effectiveness of the Cheff directive. Although the bases and scope of these powers are obscure, ${ }^{82}$ nevertheless it is well established that the Court's dis-

Barnett, Avoidance of Judicial Decision upon Constitutional Ground When Decision Can Be Based upon Other Grounds, 28 ORE. L. REv. 201 (1949); Note, 48 Corum. L. REv. 427 (1948).

A technique recently adopted by the Court has involved justifying its resolution of issues as an exercise of its supervisory power and subsequently supporting its conclusion with a constitutional basis. Compare Marshall v. United States, 360 U.S. 310 (1959), with Sheppard v. Maxwell, 384 U.S. 333 (1966). See also Thiel v. Southern Pac. Co., 828 U.S. 217 (1946); Labat v. Bennett, 365 F.2d 698 (5th Cir. 1966), 1967 DUkE L.J. 346.

59 "[W]e are constrained to view the proceedings here as equivalent to a procedure to prosecute a petty offense. . .." 384 U.S. at 379. "Cheff's offense can be treated only as 'petty' in the eyes of the statute [18 U.S.C. $\$ 1$ (1964)-see note 18 supra] and our prior decisions." 384 U.S. at 380 .

${ }^{\circ}$ Ibid. But see note 55 supra. Mr. Justice Clark's characterization of con. tempt as sui generis is important in light of the fact that the label had played a particular role in the historical development of contempt. See note 24 supra.

${ }^{81} \mathrm{Mr}$. Justice Harlan, concurring in Cheff, also interpreted the prevailing opinion as relying solely upon the Court's discretionary powers. 384 U.S. at 381 .

o2 The supervisory power was first enunciated as a basis of decision in McNabb v. United States, 318 U.S. 332, 340 (1943): "Judicial supervision of the administration of criminal justice in the federal courts imphes the duty of establishing and maintaining civilized standards of procedure and evidence." While the Supreme Court did not elaborate the precise source of this power, it appears to be neither constitutionally based, since it was specifically employed in $M c N a b b$ as an independent basis of decision, id. at 341, nor related to specific statutory authorization. See Comment, 53 GEO. L.J. $1050,1062-65$ (1965). Although its rudiments vaguely parallel the rule-making authority of English common law courts, see id. at 1053-56, the genesis of the power is probably an inherent attribute of the Supreme Court's position as the pinnacle of the federal court system. See Note, 76 HARv. L. REv. 1656 (1963). Initially announced as a 
discretionary power over the functioning of federal criminal jurisdiction, the supervisory power has subsequently been exercised to affect procedures in both administrative proceedings and civil litigation. See, e.g., Communist Party v. Subversive Activities Control Bd., 351 U.S. 115 (1956); Thiel v. Southern Pac. Co., 328 U.S. 217 (1946).

In utilizing the supervisory power to maintain "civilized standards," the Supreme Court has increasingly imposed upon the federal courts procedures more exacting than the minimum requirements of due process. For example, a petitioner seeking reversal of a state court judgment rendered on the basis of perjured testimony must make an affirmative showing of prejudice. See, e.g., Napue v. Illinois, 360 U.S. 264 (1959). Reversals have been granted to appellants from federal courts, however, when only a substantial allegation of perjury was made. See Communist Party v. Subversive Activities Control Bd., supra. But see Shotwell Mfg. Co. v. United States, 371 U.S. 341 (1963). Thus, impetus for an exercise of the power often appears to arise more from a conclusion as to the lack of fairness in a proceeding than a concern for the detriment to a particular litigant. See Thiel v. Southern Pac. Co., supra (petitioner not required to show membership in a class unjustly excluded from jury service). Compare Ballard v. United States, 329 U.S. 187 (1946), with Moore v. New York, 333 U.S. 565 (1948). See also Note, 76 HARv. L. Rev. 1656, 1659 (1963). The procedures subject to this protean power are apparently without limit absent evidence of contrary congressional intent. See id. at 1656. Thus, in light of the scope of possible applications, categorization of decisions rendered pursuant to this power is of slight significance. See, e.g., Marshall v. United States, 360 U.S. 310 (1959); Grnnewald v. United States, 353 U.S. 391 (1957); Mesarosh v. United States, 352 U.S. 1 (1956). See generally Comment, 53 Geo. L.J. 1050, 1056-78 (1965).

Because few congressional enactments have specified maximum penalties for criminal contempts, the revisory power exists to prevent abuses in the exercise of sentencing discretion. Such a power is unique to contempt procedures, for in the usual criminal case, a statutorily prescribed range of sanctions has been held to justify disallowance of appellate court revision of sentences initally imposed. See, e.g., United States v. Pruitt, 341 F.2d 700, 703 \& n.9 (4th Cir. 1965). Balancing the utility of an unconstrained contempt power in ensuring efficient judicial administration against the dangers inherent in unlimited sentencing discretion, the Supreme Court has avoided "artificial limitations on the power" and has instead vested in "appellate courts ... a special responsibility for determining that the power is not abused, to be exercised if necessary by revising themselves the sentences imposed." Green v. United States, 356 U.S. 165, 188 (1958). See also Brown v. United States, 359 U.S. 41 (1959); Yates v. United States, 356 U.S. 363 (1958); Nilva v. United States, 352 U.S. 385 (1957); United States v. UMWA, 330 U.S. 258 (1947); United States v. Harris, 367 F.2d 826 (2d Cir. 1966); United States v. Levine, 288 F.2d 272 (2d Cir. 196I). Moreover, the Court of Appeals for the District of Columbia, in the recent case of Schnurman v. United States, No. 20411, April 7, 1967, at 2, has asserted a statutory prescription for the revisory power in 28 U.S.C. $\$ 2106$ (1964): any "court of appellate jurisdiction may affirm, modify, vacate, set aside or reverse any judgment, decree, or order of a court -lawfully brought before it for review, and may remand the cause and direct the entry of such appropriate judgment, decree, or order, or require such further proceedings to be had as may be just under the circumstances."

In evaluating the fairness of an exercise of the prodigious sentencing power, an appellate court should consider (1) the flagrance of the contempt, Green v. United States, supra at 188; (2) the impartiality and adequacy of the hearing at which the sentence was imposed, Brown v. United States, supra at 52; (3) indicia of congressional intent to limit the sanction, as where a statutory maximum sentence is established for the activity subsequent to the occurrence of the contempt or where limitations have been enacted for similar offenses, see id. at 52 n.15; Green v. United States, supra at 189; (4) in cases involving multiple contemnors, the consistency of the sanctions imposed, see ibid. Thus, while the supervisory power is often exercised to establish 
cretionary power cannot be employed in contravention of either valid federal statutes or clear legislative intent. ${ }^{63}$ However, in contrast to previous instances in which the Court has utilized its policy-making authority to accord extra-statutory procedural safeguards, both the right to trial by jury and the permissible length of sentences for criminal contempt have been the subject of continued congressional scrutiny. In the instant case, Mr. Justice Clark's two-pronged directive that in all prosecutions for criminal contempt the federal courts must either limit sentences to six months imprisonment or accord jury trials is, therefore, conceivably disruptive of Congress' considered regulatory scheme for indirect contempt proceedings. ${ }^{64}$

For analytical purposes, indirect contempts arguably are divisible into three categories with respect to the appropriateness of jury trials. In the first instance, Congress has conferred a statutory right to trial by jury in three limited situations where protection of a particular class of contemnors was deemed to outtweigh considerations of judicial efficiency. ${ }^{65}$ However, where the latter element was

precedential procedural standards, the revisory power usually leads to determinations irrevocably based in the particular circumstances considered.

os "Our general power to supervise the administration of justice in the federal courts ... does not extend to disregarding a validly enacted and applicable statute or permitting departure from it, even in such matters as venue." United States v. National City Lines, 334 U.S. 573, 589 (1948). In the decision initially employing the supervisory power, the Court stated: "[In reaching our conclusion] . . . we respect the policy which underlies Congressional legislation." McNabb v. United States, supra note 62, at 347. Cf. Griffin v. United States, 336 U.S. 704, 717-18 (1949).

os In addition to the uncertainty generated with regard to indirect contempts, the directive failed to resolve the pre-existing conflict as to the applicability of the petty offense equation to direct contempts. See note 54 supra. While the precise issue in Cheff concerned only indirect contempts, Mr. Justice Clark failed to differentiate between "direct" and "indirect" contempt despite the confusion over the applicability" of the Barnett dictum. Arguably, therefore, the directive encompasses "direct" as well as "indirect" contempts. Nevertheless, several factors militate against such a construction. When breaches of courtroom decorum occur within the presence of the court itself, summary disposition seems essential to prevent delays in the judicial process and to preserve the integrity and efficiency of the judicial system. Weighed against the demands of judicial efficiency, the existing procedural requirements for direct contempts would seem adequately to protect the criminal contemnor. See FED. R. CRIM. P. 42; Harris v. United States, 382 U.S. 162 (1965); 1966 Duke L.J. 814, 819-20. Nor is the trend toward harsher sentences which precipitated the Barnett and cheff restrictions duplicated in the case of direct contempts. Finally, in the same term in which Cheff was decided the Supreme Court upheld the use of summary proceedings in a "narrow cate. gory" of contumacious conduct which poses "an open, serious threat to orderly pro. cedure" making "necessary" immediate action to preserve the efficacy of the court itself. Harris v. United States, supra at 164-65. It would therefore seem improbable that the Court would promptly overrule itself and, moreover, do so sub silentio.

${ }^{65}$ See notes $35-37$ supra and accompanying text. In granting a jury trial where the 
considered predominant, legislative history clearly evidences Congress' intent that a trial by jury should not be afforded. For example, all contempts before certain administrative and quasi-judicial officials are required by statute to be punished "in a summary manner." ${ }^{66}$ Congress has also expressly precluded jury trials in all contempt proceedings arising out of cases to which the United States is a party, primarily on the theory that juries might undermine the effective enforcement of such regulatory statutes as the Sherman Act and the Interstate Commerce Act. ${ }^{67}$ Similarly, Congress has em-

contemptuous act also constitutes a crime, the purpose seems to have been to assure a jury trial to defendants who, in defying court orders, also engaged in conduct labeled by the legislature as criminal. Before the act it was possible to enjoin the commission of crimes and, by the use of the contempt power, to "short-circuit" the criminal law. See Tailiaferro v. United States, 290 Fed. 906, 910-11 (4th Cir. 1923); H.R. REP. No. 627, 63d Cong., 2d Sess. 46 (1914); H.R. REP. No. 613, 62d Cong., 2d Sess., pt. 1, at 6 (1912); 48 CONG. REC. 8779 (1912) (remarks of Representative Clayton); cf. GoldFARB 183.

Dissatisfaction with the operation of the Clayton Act and the anti-union bias of the judiciary prompted passage of the Norris-LaGuardia Act designed to remedy only those abuses arising out of injunctions in labor disputes. See note 36 supra; SwAyzEE, CONTEMPT OF COURT IN LABOR INJUNCTION CASES 106-08 (1935); Thomas, op. cit. supra note 42, at 42-45; Chamberlain, The Federal Anti-injunction Act, 18 A.B.A.J. 477 (1932); Frankfurter \& Greene, Congressional Power over the Labor Injunctions, 31 Colum. L. REv. 385 (1931).

The jury trial provisions in the Civil Rights Act, supra note 37, were the result of various compromises in Congress. It was primarily the southern members who advocated absolute jury trial provisions in order to protect public officials. This position, and even the compromise that was reached, created difficulties for civil rights proponents who saw that the grant or requirement of jury trials could be used by southern federal district judges as a face-saving device; these judges could heed a Department of Justice request for enforcement by issuing a criminal contempt citation, but ultimately defer to segregationist sentiment by granting a jury trial. The 1964 provision was also influenced by the Barnett dictum, which was handed down in the midst of the debate, and the important role of the jury trial issue in the southern filibuster. See Goldfarb \& Kruzman, supra note 42, at 496-506.

oo See National Bankruptcy Act, ch. 541, \$41, 30 Stat. 556 (1898), as amended, 11 U.S.C. $\$ 69$ (1964) (contempts committed before a bankruptcy referee, upon certification to the judge of the bankrnptcy court, shall be punished "in a summary inanner"); 5 U.S.C.A. \$ 8125 (1966) (Special Pamphlet), formerly Government Employee's Compensation Act, ch. 458, $\$ 23$, 39 Stat. 747 (1916) (similar procedure for contempts before the Secretary of Labor or his representative); Longshoreman's and Harbor Workers' Act, ch. 509, § 23, 44 Stat. 1438 (1927), 33 U.S.C. \$927 (1964) (same).

${ }^{\circ 7} 18$ U.S.C. $\$ \S 402,3691$ (1964) (see note 35 supra). See 51 Cong. Rec. 14377 (1914) (remarks of Senator Walsh); id. at 14413, 14417 (remarks of Senator Borah). See generally Brief for the United States, pp. 40-44, United States v. Barnett, 376 U.S. 681 (1964). "The reasons which infuenced Congress are apparent. Where the United States is proceeding to enforce a public right, the defendant is afforded the safeguard of an independent and impartial determination by public officials before the proceeding is instituted-a safegnard not available in private litigation. In that situation, it was thought, the United States should have the full range of sanctions for vindicating judicial orders unmitigated by a jury's powers of dispensation." Id. at 40 . See 48 
phasized that jury trials are not to be provided for contempts of the courts of appeals since a substantial administrative burden would thereby be imposed due to the absence of existing jury machinery. ${ }^{68}$ Nor has Congress by its silence conferred unbridled discretion upon the federal courts with respect to the residuum. By providing that all contempts outside of the specified categories are to be tried "in conformity to the prevailing usages at law," which traditionally have excluded jury trials, Congress evinced a considered judgment that the efficacious administration of the judicial process requires the maintenance of summary contempt procedures. ${ }^{60}$ In addition, on

Cong. Rec. 8779, 8785 (1912) (remarks of Representative Clayton); id. at 8780 (remarks of Representative Ford); $i d$. app. at 314 (speech of Representative Davis); 51 CONG. REc. 14377 (1914) (remarks of Senator Walsh).

Furthermore, the legislative history of the Sherman Act and the Interstate Com. merce Act evinces an intent to anticipate possible frustrations to fulfillment of the policies motivating those enactments. It was apparently believed that lay juries might be either hostile to or ignorant of the purposes of the acts. Thus, to foster the uniform development of the legislative mandates where the Government could affect the results of litigation, the burden of formulating rights and remedies was placed solely upon governmental agencies and the federal judiciary with an implied belief that these instrumentalities would more likely comprehend the goals undertaken by the two statutes. See 48 CoNG. REc. 8776.809 (1912) (debate on procedurc in con. tempt cases); id. app. at 313-19 (speech of Representative Davis); cf. Comment, 65 YALE L.J. 846,859 n.74 (1956).

${ }^{8}$ Congressional recognition of the pragmatic limitation upon jury trials at the appellate level is evident from the legislative history of the jury trial provision in the Clayton Act. The first attempt to provide jury trial in antitrust contempt cases was not limited to trial courts and was opposed on the grounds that it established jury procedures "in courts where there were no jurors." 48 Cong. REc. 8778 (1912) (re. marks of Representative Clayton). A second proposal eliminated this objectionable feature, so that the bill was then "limited to proceedings in the district courts ... which courts have proper machinery for juries." Id. at 8780 (remarks of Representa. tive Ford). See H.R. 22591, 62d Cong., 2d Sess. (1912); 48 Cong. Rec. 8778 (1912) (remarks of Representative Clayton); id. app. at 314 (speech of Representativc Davis); 51 CoNig. Rec. 14374 (1914) (remarks of Senator Chilton); id. at 14414 (remarks of Senator Jones). While this bill failed to pass because of adjournment, an identical provision, H.R. 15657, 63d Cong., 2d Sess. (1914), was success[ul the following term. See S. ReP. No. 968, 63d Cong., 2d Sess. 33.42 (1914).

"Nor can it be supposed that the drafters of the Clayton Act ignored thc possibility of contempt of appellate court orders. Section 11 [of the Clayton Act] . . . expressly referred to the circuit courts of appeals in conferring power upon them to enforce orders of [certain specified administrative agencies] . . . and it must have been contemplated that disobedience of the enforcement decree might give rise to contempt.

"The plain fact is that the jury trial provision was intentionally restricted to district court proceedings. Then, as now, Congress well knew how to provide for all courts." Brief for United States, pp. 28-29, United States v. Barnett, 376 U.S. 681 (1964). See generally id. at 22-32.

18 U.S.C. $\$ \$ 402,369 \mathrm{I}$ (1964), which confer a statutory right to a trial by jury whenever the contempt also constitutes a separate crime or arises out of a labor dis. pute, pointedly declare that "all cases of contempts not specifically embraced in this 
at least three occasions, Congress has refused to enact legislation which would have substantially broadened the existing statutory jury trial provisions. ${ }^{70}$ Similarly, while the Federal Rules of Criminal Procedure were recently amended, no expansion of the jury trial procedures was undertaken despite increasing demand for legislative or judicial action. ${ }^{71}$ At best, therefore, this history of congressional inaction arguably suggests a legislative design that jury trials for criminal contempts be employed sparingly in the federal courts.

In contrast, Mr. Justice Clark acknowledged no exceptions to the jury-trial prong of the directive: where "non-petty" sentences are to be imposed, a trial by jury must be provided. ${ }^{22}$ Under the Barnett rationale any consequent conflict between the Court's pronouncement and existing statutes and congressional policy was irrelevant since by necessity the inconsistent legislative intent would be unconstitutional. However, resulting as it does from a mere judicial

section may be punished in conformity to the prevailing usages at law." The legislative history of both sections clearly indicates that the "prevailing usages" clauses were incorporated principally to ensure the preservation of the federal courts' historical power to punish criminal contemnors without according a trial by jury. See, e.g., S. REp. No. 827, 54th Cong., 1st Sess. (1896); 28 Cong. REc. 6320-21 (1896) (remarks of Senator Hill); 48 CoNG. REc. 8778 (1912) (remarks of Representative Clayton); 51 CoNG. REc. 14414 (1914) (remarks of Senator Jones), cf. note 80 infra and accompanying text.

${ }^{70}$ In the formulation of the Clayton Act, Senator Borah proposed an amendment, later defeated, which would have provided, in his words, "for jury trials in contempt cases in actions brought by the government the same as when actions are brought by private individuals." 51 Cong. REc. 14413, 14417 (1914). Eighteen years later the Senate version of Norris-LaGuardia anti-injunction proposal included jury trials "in all cases in which a person shall be charged with contempt in a court of the United States. ..." 75 Cong. Rec. 4757 (1932) (remarks of Senator Norris). After conference, the guarantee of a jury trial was restricted to contempts arising under the specific legislation considered by the conference committee. See H.R. REP. No. 821, 72d Cong., Ist Sess. (1932), reprinted in 75 Cong. Rec. 6336 (1932); 75 Cong. REc. 6450 (1932) (remarks of Senator Norris). Finally, an amendment of Senator Talmadge in the 1964 Civil Rights Act sought to provide a trial by jury in all criminal contempt cases in the federal courts, under the Civil Rights Bill or any other act of Congress. Amendment No. 513, 88th Cong., 2d Sess. (1964), reported in 110 Cong. Rec. 8649-50 (1964). However, the provision became embroiled in the tactics of cloture to cut off the southern filibuster and was itself amended to provide jury trials only under the Civil Rights Act Amendment No. 869 (1964), reported in 110 CoNG. REc. 12843, 1305051 (1964). See 110 CoNG. Rec. 12843-54, 12859-62, 12949-96 (1964) (debate on Civil Rights Act); Goldfarb \& Kurzman, supra note 42, at 496-506.

${ }_{71}$ The amended rules were transmitted to Congress on February 28, 1966, and took effect on July 1, 1966. No change occurred in rule 42, see 86 Sup. Ct. 212-30 (1966), despite suggestions for alteration. See, e.g., Comment, 65 YALE L.J. 846, 859 \& n.74 (1960); cf. GoldFaRB 282-83, 300-01.

72 See note 23 stupra and accompanying text. 
policy decision, the contrariety arguably produced by the instant case seemingly occasions an unavoidable dilemma for the Court. To comport with the traditional limitations upon the Supreme Court's discretionary powers, ${ }^{73}$ the jury-trial alternative must be deemed inoperative, at least where Congress has laid down an explicit procedure which precludes the accordance of jury trials. ${ }^{74}$ On the other hand, full implementation of the directive's prescription would necessitate not only the substantial expansion of the Court's policymaking powers but also a concomitant recognition of the Supreme Court's power to contravene congressional intent on other than constitutional grounds. In light of the improbability of the latter alternative, ${ }^{75}$ the viability of the "right" to trial by jury originally tendered in Barnett would seem to have been at least somewhat emasculated by $\mathrm{Mr}$. Justice Clark's retreat from its previous constitutional foundation.

The sentence-limitation prong of Mr. Justice Clark's directive similarly may be inconsistent with Congress' regulatory scheme for indirect contempts. Congress has statutorily prescribed the maximum sentence only where the contemptuous act also constitutes a separate crime, ${ }^{76}$ arises under certain civil rights statutes, ${ }^{77}$ or occurs before a military tribunal. ${ }^{78}$ With respect to all other contempts, Congress has expressly authorized the federal courts to punish contemnors "in conformity to the prevailing usages at law"70 under

\footnotetext{
${ }^{23}$ See note 63 supra and accompanying text.

"See notes 66.71 supra and accompanying text.

${ }^{75}$ See nate 101 infra and accompanying text.

${ }^{30} 18$ U.S.C. $\$ 402$ (1964) (originally enacted as Clayton Act $\S \S 21-22,24,38$ Stat. 738 (1914)).

77 Civil Rights Act of 1957, $\S 151,71$ Stat. 638, 42 U.S.C. $\S 1995$ (1964); Civil Rights Act of 1964, $\$ 1101,78$ Stat. 268, 42 U.S.C. $\$ 2000 \mathrm{~h}$ (1964). See note 37 supra.

${ }^{78} 10$ U.S.C. $\$ 848$ (1964) (originally enacted as Uniform Code of Military Justice art. 48, 64 Stat. $123(1950))$.

7018 U.S.C. $\$ 402$ (1964). The courts have always possessed wide discretion in imposing contempt sentences. The Judiciary Act of Sept. 24, 1789, § 17 (a), 1 Stat. 83, authorized the courts to "punish by fine or imprisonment, at the discretion of such courts, all contempts . . . before the same." The abuse of this undefined power by Judge James $H$. Peck resulted in the passage of the Act of March 2, 1831, 4 Stat. 487 (1856), which, while limiting contempts to those acts presently enumerated in 18 U.S.C. $\$ 401$ (1964), made no change in sentencing discretion. See generally Frankfurter \& Landis, supra note 35, at 1023-28. Similarly, the present statutory authorization merely' provides that "a court of the United States shall have power to punish by fine or imprisonment, at its discretion, such contempt of its authority, and none other, as-(1) Misbehavior of any person in its presence or so near thereto as to obstruct the administration of justice; (2) Misbehavior of any of its officers in their official transactions; (3) Disobedience of resistance to its lawful writ, process, order, rule, decree, or command." 18 U.S.C. $\$ 401$ (1964).
} 
which sentences are reviewable only for abuse of discretion. ${ }^{80}$ An implied endorsement of the court's relatively unconstrained sentencing discretion in this residuum may also be inferrable from Congress' increasing reliance upon the flexibility of the judicial contempt power as the primary means of enforcing administrative rulings. ${ }^{81}$ Since the regulatory mandate of many agencies encom-

\footnotetext{
${ }^{80}$ See note 62 supra. The legislative history of the "prevailing usages" clause, $c f$. notes $65,67-70$ supra, clearly indicates that its purpose was to ensure that contempts other than those explicitly governed by the statutes were to be tried according to preexisting procedures. See H. REP. No. 613, 62d Cong., 2d Sess. (1912). See generally Brief for United States, pp. 47-53, United States v. Barnett, 376 U.S. 681 (1964). Prior to the enactment of the Clayton Act in 1914, and its re-enactment in 1948, it was well established in both English and American law that the only limitation upon the courts' sentencing power for criminal contempts was that imposed by sound discretion. See, e.g., UMWA v. United States, 330 U.S. 258, 304-05 (1947); United States ex rel. Brown v. Lederer, 140 F.2d 136, 139 (7th Cir.), cert. denied, 322 U.S. 734 (1944); Warring v. Huff, 122 F.2d 64I, 642 (D.C. Cir.), cert. denied, 314 U.S. 678 (1941); Creekmore v. United States, 237 Fed. 743, 754-55 (8th Cir. 1916), cert. denied, 242 U.S. 646 (1917); In re Maury, 205 Fed. 626, 632 (9th Cir. 1913); Carter v. Commonwealth, 96 Va. 791, 811 (1899). See generally THomas, op. cit. supra note 42, at 10; Note, Civil and Criminal Contempt in the Federal Courts, 57 YALE L.J. 83, 99 (1947). Therefore, Congress' specific incorporation of sentencing discretion would seem to evince Congress' considered judgment that on balance both the adequate protection of contemnors and judicial efficiency were best served by preserving the courts' discretion in all but narrow circumstances. $C f$. note 83 infra and accompanying text. See generally Brief for United States, pp. 39-60, United States v. Barnett, 376 U.S. 681 (1964).

BI See Jaffe, supra note 43, at 907, 914; cf. id. at 871. Numerous provisions authorize judicial enforcement of administrative rulings through the contempt power. See statutes cited note 43 supra. While flexibility of remedy probably influenced the choice of the contempt power for enforcement, a major consideration was to insure judicial review of administrative action. Sec Jaffe, supra note 43 at 865-67; cf. Note, 1966 DUke L.J. 841, 843 n.16. An agency order once issued is reviewable judicially in a court of appeals. If the legal and factual basis of the order is sustained, the court enforces the order by judicial decree. See, e.g., National Labor Relations Act $\$ 11$ (2), 61 Stat. 147 (1947), 29 U.S.C. $\$ 161$ (2) (1964). Violations of agency orders do not ordinarily become subject to the contempt power until such review has taken place. Sce Jaffe, supra note 43 , at 869 .

The criticisms directed against summary contempt procedures would seem inapplicable to enforcement order proceedings, for the enforcement order is usually proceeded by a long legal proceeding in which facts and specific issues have been determined. See Comment, 54 Colum. L. Rev. 603, 607-10 (1954). Thus, those accused have been able to refine, in both administrative and judicial actions, the legal and factual issues underlying the duty imposed. See, e.g., Federal Trade Comm'n Act $\S 5$ (c), 52 Stat. 112 (1938), as amended, 15 U.S.C. $\$ 45$ (c) (1945). See generally Jaffe, The Right to Judicial Review (pts. 1-2), 71 Harv. L. REv. 401, 769 (1958). "They [the defendants] have been personally ordered to conduct themselves in a specific manner, and have had the opportunity-before being placed under a legal obligation to obey-to test the legal sufficiency of the order which imposes the legal duty upon them." Brief for the United States, pp. 16-17, Cheff v. Schnackenberg, 384 U.S. 373 (1966). See generally id. at 11-19. Because of the safeguards which have been afforded to the contemnor in this instance, including a clear delineation of his obligations, limitation of sentence to six months, regardless of the flagrance involved, is unnecessary and arguably undesirable.
} 
passes a gamut of possible violations, adjustment of the penalty to the violation could be best achieved by the incorporation of the protean sanctions of the contempt power. More significantly, however, the continued absence of further statutory regulation appears to manifest a congressional acceptance of the historical postulate that, in general, sentencing discretion is indispensable to the proper functioning of the judicial system..$^{82}$ In the first instance, the unique nature of the three specific classes of contemnors for whom maximum sentences have been statutorily provided would seem to indicate that Congress will divest the courts of their traditional discretion over contempt sentences only under the most compelling circumstances, such as when the possibility of prejudicial abuse of discretion is particularly significant.83 Furthermore, the federal scheme has been maintained despite its variance from state procedure under which, by contrast, comprehensive statutory delineation of maximum sentences for all categories of contempt is the norm. ${ }^{84}$

\footnotetext{
${ }^{82}$ See note 28 supra and accompanying text.

${ }^{88}$ In the case of a contemptuous act which also constitutes a crime, the same logic that compels a jury trial seemingly applies to deny complete sentencing discretion: the court might impose a sentence for the contempt which exceeds the statutory maximum for the crime. See note 65 supra. Further, although the reasoning behind limitation upon judicial discretion in contempts under the Civil Rights Act is clouded by the act's congressional history, ibid., the intent seems to have been to protect civil rights violators from severe sentences. Finally, the limitation of contempt sentences in military tribunals flows from a general congressional desire to afford some protection to the military defendant to compensate for dangers inherent in lower level court martials where the defendant is without counsel to advise him with respect to the consequences of his courtroom actions and is tried by officers without a jury. See 59 CoNG. REC. $5836-43$ (1920) (Articles of War amendment offered by Senator Chamberlain); $i d$. at 5843-45 (remarks of Senator Chamberlain).

81 The statutes of twenty-six states limit the maximum punishment which may be imposed for contempt to six months or less. ALA. CODE tit. $3, \S 9$ (1958) (supreme court: ten days; circuit courts: five days; other courts: six to twenty-four hours); ALASKa Stat. \$09.50.020 (1962) (six months); ARK. Stat. ANN. \$34.902 (1947) (ten days or until adjournment of court); Cal. Civ. Proc. CODE \$1218 (five days); ConN. Gen. Stat. ANN. \$\$31-119, 51-33 (1949) (six months); Hawall REv. Laws \$269-1 (1955) (trial by jury: two years; summary punishment by supreme court: sixty days; by circuit court: thirty days; by other courts: ten days); IDAHo CODE ANN. \$7.610 (1948) (five days); IND. ANN. STat. \$ 3.906 (1946) (three months); Iowa Code $\$ 665.4$ (1962) (six months); KY. REv. STAT. $\$ 432.260$ (1960) (maximum without jury trial: thirty days); LA. REv. STAT. § 15:11 (1950) (ten days); Mich. STAT. ANN. \$27A.1715 (1962) (thirty days); MINN. STAT. ANx. $\$ 588.10$ (1947) (six months); Miss. CODE ANN. $\$ 1656$ (1956) (thirty days); MoNT. REv. Codes ANx. \$93-9810 (1964) (flve days); Nev. REx. STAT. $\$ 22.100$ (1957) (conflicting-twenty-five dajs); N.Y. JudiciarY LAW $\$ 751$ (thirty days); N.C. GEN. STAT. \$5-4 (1953) (thirty days); N.D. CENT. CodE \$27-10.62 (1960) (thirty days); OHIo Rev. CODE ANs. $\$ 2705.05$ (Page 1954) (ten days); ORE. REv. STAT. $\$ 33.020$ (1965) (six months); TENN. CODE ANN. \$23.903 (1955) (circuit, chancery, and appellate courts: ten days; others: fine only); TEx. REv. Civ. STAT. ANN. arts. 1736, 1826, 1911, 1955 (1964) (supreme court and court of civil appeals: twenty days; district
} 
Mr. Justice Clark's recognition of a continuing necessity for sentencing discretion over contempts seems implicit in the alternative provided by the Cheff directive. Since the six months maximum prescribed by the sentence-limitation prong is inapplicable where a jury trial is provided, the directive theoretically perpetuates the courts' relatively unfettered power to punish criminal contemnors. However, the effective implementation of this discretion arguably would seem to have been impaired by the prevailing opinions' imposition of the potentially burdensome precondition that a jury trial must be provided, ${ }^{85}$ for there would appear to be innumerable instances in which the jury-trial alternative would be either unavailable due to statutory proscription ${ }^{86}$ or impracticable in light

and county courts: three days); UTAF CoDE ANN. $\$ 78-32-10$ (1953) (thirty days; justice of the peace: one day); WASF. REv. CODE $\$ 7.20 .020$ (1956) (six months); WIS. STAT. $\$ 256.06$ (1963) (thirty days).

In eighteen states, however, either no limitation is placed on contempt sentences or the limitation is in excess of six months. DEL. SUPER. CT. (CRIMr.) R. 42 (1953) (similar to Fed. R. CRIM. P. 42, note 31 supra); Fla. STAT. ANN. $\$ 38.22$ (1944) (only limitation on justice of the peace); GA. Code ANN. \$24-105 (1959); ILL. Stat. ANN. ch. 38, \$ 1-7 (1961) (limits an undefined sentence to one year), People v. Stellar, 31 III. 2d 154, 201 N.E.2d 97, cert. denied, 380 U.S. 912 (1964) (statute inapplicable to contempt of court); KAN. GEN. STAT. ANN. \$\$20-1204, 21-111 (1964) (limit upon undefined sentence: one year); ME. Rev. STAT. ANN. tit. 14, § 252 (1965); MD. ANN. COdE art. 26, §4 (1957); Mo. ANN. STAT. $\$ 476.120$ (1952); NEB. REv. STAT. $\$ \$ 25-2122,-2123$ (1964); N.J: STAT. ANN. \$ 2A:85-7 (1952) (criminal contempt is a misdemeanor. State v. Janiec, 25 N.J. Super. 197, 95 A.2d 762 (Super. Ct. 1953); when no punishment is fixed, the maximum is three years); N.M. STAT. ANN. \$\$ 16-1-2 (1953), 36-16-2 (Supp. 1964) (only limitationjustice of the peace: three days); R.1. GEN. LAws ANN. \$ 8-6-1 (1956); S.C. CODE ANN. $\$ \S 10-1738,15-231.1$ (1962); S.D. CoDE $\$ \S 13.1235, .0607$ (1939), 33.3703 (Supp. 1960) (guilty of misdemeanor-maximum one year; Justice Court limited to one day); VT. STAT. ANN. tit. 12, $\$ 123$ (1959); VA. CODE ANN. $\$ \$ 18.1-292,-293$ (1960) (courts not of record limited to ten days); W. VA. CODE ANN. $\$ 61-5-26$ (1961); Wyo. STAT. ANN. $\$ 1-669$ (1957) (justice of peace: two days).

Only three states require a jury trial upon the demand of the defendant. ARIz. REv. Stat. ANN. $\$ 12-863$ (1956) (maximum penalty is still six months); OKLA. Stat. ANN. tit. 21, §567 (Supp. 1964); PA. Stat. ANN. tit. 17, § 2047 (c) (1962).

The laws of three states do not contain any general contempt provisions. Rather, various specific acts are considered to be contempts. E.g., Colo. Rev. Stat. ANN. $\$ \S 80$. $11-9,139.84-11,139.85-11$ (1963) (right to jury trial in cases involving labor disputes; police courts: maximum sentence is five days); MAss. ANN. LAws ch. 220, $\$ 13 \mathrm{~A}$ (1955) (right to jury trial in cases involving labor disputes); N.H. Rev. StAT. ANN. \$§544.16, $.17, .40$ (1955) (violation of injunction against a continuing nuisance: six months maximum).

${ }^{80}$ On the other hand, many foreign jurisdictions severely constrict the permissible punishment for criminal contempt. See, e.g., Bigelow, Contempt of Court, I CRIM. L.Q. 475 (1959) (in Canada maximum punishment for failure to obey process is 100 dollars and ninety days; maximum punishment for refusal to obey court orders is eight days); Jann, Contempt of Court in Western Germany, 8 AMER. U.L. REv. 34 (1959) (maximum one day imprisonment in Western Germany for direct contempts). ${ }^{80}$ See notes 66-70 supra and accompanying text. 
of the attendant expense, delay, inconvenience, or unavailability of jury trial machinery. ${ }^{87}$ Under these circumstances a court could impose no more than a six months sentence, regardless of the egregiousness of the contempt, arguably thereby severely constricting, in apparent contradiction of congressional policy, a trial court's ability to determine appropriate sentences for contempts on an ad hoc basis. Finally, since jury trials for disobedience of courts of appeals' orders enforcing administrative determinations would seem to be either unavailable or impracticable, ${ }^{88}$ the directive would also seem to undermine congressional reliance upon the contempt device as the basic enforcement mechanism for administrative agencies. ${ }^{80}$ The sentence-limitation prong of the directive, therefore, conceivably confronts the Court with a dilemma similar to that generated by the jury-trial alternative: either the traditional limitations upon the

${ }^{87}$ A mandatory jury trial seems most burdensome when hte contemnor's refusal to comply is based solely on legal grounds. In such a case, the function of a jury is unclear, for the primary issue-whether a sufficient legal justification exists for noncompliance-is not within the competence of a fact finder. Resolution of the factual issue of whether there was actual noncompliance appears to be so elemental as to render formalistic and economically unjustifiable any empaneling of a jury. Unnecessary delays may occur in other situations as well. For example, resolution of the facts of many contempts is often necessary before final adjudication can be made of the case in which the contempt occurred. In many proceedings, it would be necessary to ascertain immediately whether a juror was bribed or a party was improperly influenced to move for dismissal of an action. See Comment, 65 YALE L.]. 846, 855-56 (1956). In order to avoid protraction of the principal proceeding, an immediate investigation by the judge would in many cases seem preferable to a compulsory empaneling of another jury, or, where the original jury is retained, a stay in the underlying proceeding. Also, some facts of the principal case, such as whether particular records actually existed, might be relevant to the prosecution of the contemptuous activity. Resubmission of evidence and arguments on these matters seem to be an unnecessary duplicity.

It has been argued that, in many situations, summary punishment by the court is necessary to preserve a quick and efficient response to refusals to ohserve judicial mandates. See id. at 855-57. This analysis apparently presumes that the deterrent effect of contempt proceedings would be diminished if prosecution were left to the discretion of a district attorney rather than with the individual judge who could enforce immediate sanctions. But see GoLDFARB 182.

${ }^{s 8}$ Presently, no well established procedures exist for empaneling of juries in courts of appeals. If this deficiency forecloses the jury-trial alternative of the Cheff directive, sentencing for criminal contempts in these courts would appear limited by the six. month maximum prescribed by the Supreme Court. As an alternative to limiting sentences in this manner, these intermediate courts could refer prosecutions to the district courts, even though the statutory basis for such referral and the precise method of presentation of such a case remain undefined. Further, an examination of the precedents cited in note 44 supra reveals that a six-month limitation on sentences for refusals to obey enforcement orders would substantially alter the current view of enforcement discretion.

so See note 81 supra and accompanying text. 
Supreme Court's discretionary rule-making authority must be disavowed or the directive must be reformulated, if not revoked, so as to avoid disruption of Congress' regulatory scheme. ${ }^{90}$

While most of the aforementioned conflicts between the directive and congressional policy might be avoided through a more limited interpretation of legislative history, ${ }^{91} \mathrm{Mr}$. Justice Clark apparently considered legislative intent immaterial despite respondent's arguments to the contrary. ${ }^{92}$ However, in light of the potential conflicts created, this disregard of congressional intent by the Court would seem to be highly improvident, particularly in light of the Court's failure to articulate countervailing policy considerations.

Moreover, positing a conflict between the directive and congressional policy, the Court's reliance upon non-constitutional grounds to support a unilateral alteration of Congress' regulatory scheme may also unnecessarily engender a separation of powers

\footnotetext{
${ }^{\circ 0}$ See notes 73-76 supra and accompanying text.

${ }^{21}$ Other possible interpretations of the congressional intent evinced by statutory limitations on jury trials and sentencing discretion are not necessarily inconsistent with the Cheff directive. More specifically, it is arguable that the restrictions upon the availability of jury trials were intended not to prohibit such procedures generally, but rather merely to remove a demandable right to them. See notes 66.69 supra and accompanying text. In order to fulfill the purposes of the Clayton Act, for example, Congress conceivably sought to avoid allowing the contemnor to take advantage of any popular feeling against organized labor except in cases where the judiciary deemed the need for the safeguards of a jury trial to outweigh the consequences of a possible frustration of the act's objectives. Thus, the grant of jury trals for a general class of contempts under the Cheff directive, as an exercise of judicial discretion to preserve procedural fairness, could not be said to be contrary to this type of legislative intent.

Similarly, it is arguable that the limitations upon sentences for some contempts (see notes 76.78 supra and accompanying text) reflect a general dissatisfaction with the discretion of courts to sentence contempts without regard to the traditional rights of the defendant. Again, the directive comports with the objective of these congressional limitations, for the protection of jury procedures is afforded to all who are to receive "non-petty" sanctions.

The issue of congressional intent would, of course, be irrelevant had the Cheff directive been constitutionally based. See notes 56-60 supra and accompanying text. Also, the significance of any conflict between the directive and statutory objectives could have been diminished by an amendment to the Federal Rules of Criminal Procedure, for the enactment granting the Supreme Court authority to promulgate those rules provides that all conflicting laws will be superseded. See 18 U.S.C. $\$ 3771$ (1964); note 113 infra and accompanying text.

92 While the. Brief for the United States in Cheff contained little discussion of legislative history, it expressly incorporated the United States' Briefs in Green and Barnett, both of which contained lengthy discussions of the legislative history of the Clayton Act provisions now codified as 18 U.S.C. $\$ \S 402,3691$ (1964). See Brief for the United States, p. 7, Cheff v. Schnackenberg, 384 U.S. 373 (1966); Brief for the United States, pp. 44-53, Green v. United States, 356 U.S. 165 (1958); Brief for the United States, pp. 20-44, United States v. Barnett, 376 U.S. 681 (1964); notes 67-69 supra and accompanying text. See also note 81 supra and accompanying text.
} 
question. The chief obstacle to a clear delineation of the respective legislative and judicial roles in the formulation of contempt procedures lies in the obfuscated conceptual underpinning of the summary contempt power. Initially, courts and commentators had argued that the power to punish contempts summarily was necessarily embodied in "the Judicial Power" conferred upon the federal courts by article III $^{93}$ as an essential prerequisite of a viable judicial system and thus was beyond the zone of congressional definition or limitation. ${ }^{94}$ With respect to indirect contempts, however, the "inherency" theory was substantially repudiated in Michaelson $v$. United States, ${ }^{95}$ wherein the Supreme Court upheld the constitutionality of the maximum sentence and jury trial provisions of the Clayton Act. ${ }^{98}$ In so doing, the Court held that Congress possessed paramount authority to define and regulate indirect contempts as a necessary incident of the power to establish the lower federal courts conferred by articles $I^{97}$ and III. ${ }^{98}$ The only limitation upon Con-

Qs U.S. Const. art. III, $\$ 1$.

94 The Ninth Circuit in Michaelson v. United States, 291 Fed. 940, 946 (9th Cir. 1923), rev'd, 226 U.S. 42 (1924), had argued that "Congress, the agency to exercise the legislative power of the United States, can, as a potter, shape the vessel of jurisdiction, the capacity to receive; but, the vessel having been made, the judicial power of the United States is poured into the vessel, large or small, not by Congress, but by the Constitution." The court relied upon dicta in In re Debs, 158 U.S. 564 (1894), to the effect that the power to punish for contempt is an inherent power of the courts and concluded that the jury trial and sentencing provisions of the Clayton Act were therefore an unconstitutional limitation upon the courts' inherent powers. 291 Fed. at 946-47. In Debs the Supreme Court asserted that "the power of a court to make an order carries with it the equal power to punish for a disobedience of that order, and the inquiry as to the question of disobedience has heen, from time immemorial, the special function of the court. And this is no technical rule. In order that a court may compel obedience to its orders it must have the right to inquire whether there has been any disobedience thereof. To submit the question of disobedience to another tribunal, be it jury or another court, would operate to deprive the proceedings of half its efficiency. ... A court without the power effectually to protect itself against assaults of the lawless, or to enforce its orders, judgments, or decrees against the recusant parties before it, would be a disgrace to the legislation, and a stigma upon the age which invented it." In re Debs, supra at 594-95 (dictum). See also Frankfurter \&. Landis, Power of Congress over Procedure in Criminal Contempts in "Inferior" Federal Courts $A$ Study in Separation of Powers, 37 HARv. L. REv. 1016.17, 1023-27 (1924); Cheff v. Scbnackenburg, 384 U.S. 373, 384.86 (1966) (Douglas, J., dissenting). See generally In re Debs, supra at 594-600.

os 266 U.S. 42 (1924).

${ }^{\circ}$ Id. at 66-67. See note 35 supra.

7 U.S. CoNST. art. I, § 8[9].

${ }^{88}$ U.S. Consr. art. III, $\S 1$. The Michaelson Court found the statutory grant of jury trial to impose "a valid restriction upon the inherent judicial power of the United States District Courts," 266 U.S. at 70-71, and observed that "the power to punish for contempts is inherent in all courts, has been many times decided and may be regarded 
gress' regulatory power recoguized by the Michaelson Court was that under such regulation "the attributes which inhere in [the contempt] ... power and are inseparable from it can neither be abrogated nor rendered practically inoperative."90 As a result, while the federal courts may possess the inherent power to regulate the prosecution and punishment of direct contempts, ${ }^{100}$ the courts' power over in-

as settled law. It is essential to the administration of justice. The courts of the United States, when called into existence and vested with jurisdiction over any subject, at once became possessed of the power. So far as the inferior federal courts are concerned, it is not beyond the authority of Congress ...." Id. at 65-66, citing Ex parte Robinson, 86 U.S. (19 Wall.) 505, 510-11 (1873), wherein the Court said, "The moment the courts of the United States were called into existence and invested with jurisdiction over any subject, they became possessed of this power [to punish contempt]. . . . These courts were created by act of Congress. Their powers and duties depend upon the act calling them into existence, or subsequent acts extending or limiting their jurisdiction." See also Bessette v. W. B. Conkey Co., 194 U.S. 324 (1904); In re Debs, 158 U.S. 564, 595 (1895); Eilenbecker v. Plymouth County, 134 U.S. 31, 36 (1890). See generally RAPALJE, Contempt $\$ 4$ (1890); Note, 11 VA. L. Rev. 639 (1925).

${ }^{\circ 0} 266$ U.S. at 66 . The significance of the Michaelson enunciation of the range of potential congressional limitations upon the contempt power may be more concentual than substantive, for no attempt was made to define the "attributes which inhere" in the contempt power. If one of these attributes is wide discretion as to the procedural safeguards to be employed in disposition of a contempt action, the Court's pronouncement would leave Congress without meaningful regulatory power. However, the Supreme Court's subsequent use of the Michaelson precedent recognizes a broad range of traditional judicial powers subject to congressional regulation. For example, in Sprague v. Ticoni Nat'1 Bank, 307 U.S. 161, 164-65 (1939), the Court used the Michaelson interpretation to establish that principles employed in English equity courts at the time of the Constitution are applicable in the federal court subject to limitation by statute. See also Green v. United States, 356 U.S. 165, 202 (1958) (dissenting opinion). Despite the breadth ascribed to the Michaelson endorsement of congressional regnlation of contempt procedures, some commentators seem unwilling to concede that the federal courts will expose the gamut of traditional judicial powers to legislative limitations. See Van Hecke, Trial by Jury in Equity Cases, 31 N.C.I. REv. 157, 172 (1953); Note, 74 HARv. L. REv. 1176, 1177 (1961).

For a comprebensive survey of the acts of Congress inhibiting the exercise of judicial power, see Frankfurter \& Landis, supra note 94, at 1018-20 \& app. I, 1059-1100 (1924). See generally Comment, 43 CoRNell L.Q. 622 (1956).

${ }^{200}$ The power of courts to regulate direct contempts has received only slight modification of its common law form. FED. R. CRIM. P. 42 (a) specifically preserves a court's right to dispose of a direct contemnor summarily. The only significant limitation upon this power has been judicially rather than legislatively imposed. Harris v. United States, 382 U.S. 162 (1965) (see note 31 supra), limits the category of contempts which can be disposed of without hearing or notice to those which present an immediate interference with judicial administration. In addition, limited contraction of the traditional view of what constitutes "in the presence of the court" has been imposed. Compare Savin, Petitioner, 131 U.S. 267 (1889) (contempt occurring in hallway of court house deemed "direct"), with Farese v. United States, 209 F.2d 312 (Ist Cir. 1954) (threatening conversation in hallway not "in the presence of the court"). See also Nye v. United States, 313 U.S. 33 (1941).

Furthermore, despite the Green-Barmett-Cheff evolution of jury trial procedures in indirect contempts, no positive judicial reference has been made to a similar safeguard 
direct contempt would appear to be restricted to taking interstitial action consistent with underlying legislative intent. Since Michaelson upheld Congress' power to modify the courts' discretionary power over criminal contempt by delineating maximum sentences and according jury trials, it would seem axiomatic that a congressional intent that this discretion should remain unlimited would not exceed Congress' authority. Therefore, unless Mr. Justice Clark sub silentio resurrected the "inherency theory," implementation of the Cheff directive, to the extent that its mandate would contravene a statutory prescription or clear congressional policy, would seem to constitute an unwarranted invasion of Congress' legislative function by the Supreme Court. ${ }^{101}$

for direct contempts even though the need has been argued. See GoldFArs 291, 30102; Comment, 65 YALE L.J. 846, 858 (1956). Since a direct contempt, by definition, occurs in the presence of the court, the potential interference may be sufficient to justify continuation of the broad power currently available for summary disposition of this variety of contempt. See Harris v. United States, supra at 164; Beale, Contempt of Court, Criminal and Civil, 21 HARv. L. REv. 161-67 (1908); Tefft, supra note 54, at 131. At a minimum, the category of immediate disruptions delineated by the Harris rationale would appear to be most efficiently disposed of by summary prosecution. The delay and inconvenience attendant an empanelling of an independent factfinder seems unnecessary, since the judge has empirically examined the interference and has witnessed its effect upon the principal proceeding. See Beale, supra at 161-67. Even those suggesting curbs on judicial discretion in the disposition of direct contemnors are unwilling to concede that all summary procedures be eliminated. See GoLdFArB 301-06; Comment, 65 YaLE L.J. 846, 858 (1956).

${ }^{101}$ Any resultant conflict between the Cheff directive and existing statutes and legislative intent, or even the mere disregard of such a potential conflict, would scem to raise a significant separation-of-powers question. Frankfurter and Landis, in considering congressional authority to regulate the judicial contempt power, recoguize that "at the bottom of our problem lies the doctrine of the separation of powers." Frankfurter \& Landis, supra note 94, at 1012. This doctrine has never been employed as a direct basis for invalidating an act of a governmental branch. Cf. Principality of Monaco v. Mississippi, 292 U.S. 313 (1934); Kilbourn v. Thompson, 103 U.S. 168 (1880); Scott v. Sanford, 60 U.S. (19 How.) 393 (1857). See generally HaINES, TuE american Doctrine of Judicial Supremact (1959); Wade \& Philitips, Constitutional LAw 21-35 (6th ed. 1960); Fox, Separation of Powers, 5 WASH. \& LEE L. REv. 185 (1948); Frankfurter \& Landis, supra note 94 . Some members of the Court have proposed that congressional intent be accorded a "relevant and highly persuasive" weight when allocation of authority between the legislative and judicial branches is at issue. $C f$. Glidden Co. v. Zdanok, 370 U.S. 530, 542 (1962) (Harlan, J.); 49 CoRNELL. L.Q. 122 (1963). This view, when evaluated in light of the premise of the doctrine of separation of powers that "the persons intrusted with power in any one of these branches shall not be permitted to encroach upon the powers of the other," Kilbourn v. Thompson, supra at 190-91, would seem to compel the Supreme Court, particularly after its Michaelson interpretation, to give deference to the expressed congressional objectives as to allowance of jury trials in contempt proceedings. At a minimum, the Court would seem obliged to choose the congressionally desiguated alternative-amendment of rule 42-which could achieve the Cheff result without the encroaching implications attendant to that decision. See note 113 supra and accompanying text. 
Regardless of the resolution of the foregoing substantive questions, Mr. Justice Clark was similarly adumbrative with respect to the proper remedy for a breach of the directive. In situations where a trial court has imposed a sentence exceeding six months imprisonment without providing a jury trial, a reviewing court would appear to have two alternatives: either to exercise its revisory power to reduce the sentence to six months or to remand for retrial before a jury. Under the Barnett rationale, the latter alternative would have been compelled since the contemnor would have been denied his constitutional right to trial by jury by the imposition of the initial sentence, a right which could not be divested through the mere reduction of the penalty imposed. ${ }^{102}$ However, since the Cheff directive is not constitutionally bottomed, it is probable that appellate courts will generally resort to the reduction of sentences in light of the expense and delay attendant remand and retrial. ${ }^{103}$ Moreover, the prevailing opinion's promulgation of the directive "under the peculiar power of the federal courts to revise sentences in contempt cases"104 may indicate that this was the sole remedy envisaged. ${ }^{105}$

If reduction of sentence is the remedy adopted, however, a contemnor would have a right to trial by jury whenever a "non-petty" sentence was to be imposed, but that "right" would be unenforceable

${ }^{102}$ In the usual case where the defendant had been wrongly denied the right to jury trial, the decision is reversed and remanded for jury trial rather than being modified through a reduction in sentence. See, e.g., Wilson v. Bohlender, 361 U.S. 281 (1960) (military trial); Grisham v. Hagan, 361 U.S. 278 (1960) (same); District of Colunnbia v. Colts, 282 U.S. 63 (1930) (remand for new trial affirmed); Latiolais v. United States, 129 F.2d 323 (5th Cir. 1942) (memorandum decision) (Congress had not conferred jurisdiction on the district courts to try petty criminal offenses without a jury); Smith v. United States, 128 F.2d 990 (5th Cir. 1942) (same); Freeman v. United States, 227 Fed. 732 (2d Cir. 1915) (trial by jury means having same judge and jury throughout); Low v. United States, 169 Fed. 86 (6th Cir. 1909) (waiver of trial by jury invalid).

103 The appellate courts have resorted to reduction of sentence with regard to those cases in the course of appeal at the time of the Cheff decision. United States v. Harris, 367 F.2d 826 (2d Cir. 1966) (per curiam); United States v. Temple, Nos. 10653, 10654, 10655, 10656, 10698, 4th Cir., November 17, 1966; Schnurman v. United States, No. 20411, D.C. Cir., April 7, 1967.

104384 U.S. at 380 . See note 62 supra and accompanying text.

106 The preference of appellate revision over remand for a jury trial is supported by the Court's statement that "nothing we have said, however, restricts the power of a reviewing court, in appropriate circumstances, to revise sentences in contempt cases tried with or without juries." 384 U.S. at 380 . Unless the Court in some way intended a revision of contempt sentences by virtue of the directive, all mention of the revisory power in the opinion would be superfluous, for the grant of a new trial in no way involves the revision of sentence-conviction and judgment alike are vacated. 
on appeal if denied by the trial court. This result might be supported on the grounds that the imposition of a sentence greater than six months in length, absent a jury trial, arguably is analogous to the infliction of a sentence in excess of a statutory maximum for which the proper remedly is reformation of the sentence. ${ }^{106}$ On the other hand, the more persuasive argument would appear to be that the imposition of a "non-petty" punishment conclusively determines that the contempt involved is sufficiently severe to require the jury trial safeguard prerequisite to the imposition of a "serious" penalty. ${ }^{107}$ Therefore, the appellate court would be required to remand for retrial by a jury in all cases. The foregoing rationale would seem to comport more closely with the directives's raison d'être that serious penalties and "civil disabilities" should not be imposed without the protection afforded by a jury. ${ }^{108}$

${ }^{108}$ When a court has imposed a sentence in excess of statutory limits the most often used remedy is reduction by the appellate court. See Robinson v. United States, 383 F.2d 323 (8th Cir. 1964); D'Allessandro v. United States, 90 F.2d 640 (3d Cir. 1937); Simmons v. United States, 89 F.2d 591 (5th Cir. 1937); Johnson v. United States, 32 F.2d 127 (8th Cir. 1929); Spirou v. United States, 24 F.2d 796 (2d Cir. 1928). In the remainder of cases, the appellate court has remanded with a direction to resentence within the statutory limit. See Williams v. United States, 168 U.S. 382, 389 (1897) (dictum) (new trial granted for other reasons); Kitt v. United States, 138 F.2d 842 (4th Cir. 1948); Millich v. United States, 282 Fed. 604 (9th Cir. 1922); Wechsler v. United States, 158 Fed. 579 (2d Cir. 1907); Whitworth v. United States, 114 Fed. 302 (8th Cir. 1902).

${ }^{107}$ An analogy can be made to the increased-sentencing cases wherein the penalty originally imposed becomes the maximum permissible upon a retrial; the first trial judge is deemed to have determined the maximum seriousness of the defendant's offense. See Patton v. North Carolina, 256 F. Supp. 225, 235 (W.D.N.C. 1966), 1966 DUKE L.J. 1172. The reverse of this argument is that the infliction of "non-petty" punishment conclusively determines that the contempt is in fact serious and thus the defendant is entitled to a jury trial on remand. See also note 102 supra.

${ }^{203}$ The initial imposition of a "non-petty" punishment, even if later rejected on appeal, seems to render conclusive the implication that the offense is of a type to which procedural safeguards should attach. Reasonable deference to the personal rights of the defendant would seem to require that the restraints actually placed upon him be adjudicated within traditional limitations, since he is faced with the possibility of extended confinement and severe personal degradation. See 384 U.S. at 384.86 (Douglas, J., dissenting); note 55 supra. Furthermore, if safeguards are constitutionally compelled in instances where particular offenses evince "non-petty" attributes, see United States v. Barnett, 376 U.S. 681, 726-27 (1964) (Black, J., dissenting); GoLDFARB 183-84; note 5 supra, these procedural guarantees could not be rendered moot by a mere discretionary sentence revision by an appellate court, cf. note 62 supra, but rather would seem to attach irrevocably to any disposition of the case. See also Tefft, United States v. Barnett, "Twas a Famous Victory," 1964 SUP. Cr. REv. 123, 135; Note, 63 Mich. L. REv. 700 (1965).

Moreover, the mandatory remand for trial by jury of all contempts wherein the six-months limitations has been exceeded would also forestall the imposition of such excessive sentences by a trial court knowing that, at worst, the sentences would merely 
Despite the perplexities generated by Mr. Justice Clark's rationale, the practical result of the Cheff directive is belatedly to mitigate the anomalous exemption of criminal contempt from the constitutionally guaranteed right to trial by jury. The ultimate removal of this anomaly, however, would seem to require the adoption of the constitutional demarcation urged by Justices Douglas and Black. ${ }^{109}$ Not only would there appear to exist no satisfactory analytical distinction between "indirect contempts" and "crimes," 110 but the single practical effect of their merger would be to accord the additional right to trial by grand and petit juries.111 Arguably, if criminal contempt is deemed so "serious" as to require trial by jury, perforce indictment by a grand jury would also seem required.112

be reduced to six months on appeal. For example, a court which became aware of the seriousness of the contemnor's act only after deciding not to grant a jury trial might impose a sentence in excess of six months upon the theory that even if an appeal is taken, the judgment will in all probability merely be reduced to six months. Since this is the maximum sanction the juage could have imposed at the original sentencing, the court's abortive attempt to impose a serious penalty for what was considered a serious contempt has not reduced the choice of penalties.

${ }^{109}$ See 384 U.S. at $891-93$ (Douglas, J., dissenting).

110 See note 55 supra.

${ }^{111}$ Previous decisions of the courts have accorded all other criminal procedural safeguards. See note 34 supra and accompanying text.

${ }^{112}$ If criminal contempt is so serious as to require a jury trial, it arguably assumes the character of a crime and falls within the requirement of the fifth amendment that "no person shall be held to answer for a capital, or otherwise infamous crime, unless on a presentment or indictment of a Grand Jury ...." U.S. CoN\$T. amend. V. A crime is made "infamous" partly by the quality of the punishment which may be im. posed. Ex parte Wilson, 114 U.S. 417 (1885). While the Court has held that an offense with a maximum penalty of six months imprisonment can be tried without indictment, Duke v. United States, 301 U.S. 492 (1937), a potential confinement of one year has been deemed to require fifth amendment procedures, see Mackin v. United States, 117 U.S. 348, 352 (1886). Thus, the line of demarcation, which fall between six months and one year, could be expressed in the same terms as the Cheff directivesentences exceeding six months. See also Green v. United States, 365 U.S. 165 (1958); United States v. Moreland, 258 U.S. 433 (1922); In re Bonner, 151 U.S. 242 (1894); In re Mills, 135 U.S. 263 (1890). However, the mandatory indictment process has been held to be inapplicable to proceedings in which no "crime" is charged, even though the prosecution may result in a punishment which would have entitled the accused to a grand jury hearing had his offense constituted a "crime." See Beland v. United States, 128 F.2d 795 (5th Cir.), cert. denied, 317 U.S. 676, rehearing denied, 317 U.S. 710 (1942). Thus, the sui generis nature of contempt arguably removes tbat offense from classification as a "crime" and renders the indictment procedure unavailable. See note 60 supra.

In addition to consideration of the punishment imposed, the Supreme Court has indicated that the need for a graud jury proceeding also depends upon the consequences to the accused if he should be found guilty. Ex parte Wilson, supra at 423. In light of these criteria, the civil disabilities attaching to contempt prosecutions would seem sufficiently serious to necessitate the use of indictment procedures. See note 55 supra. See also GoldFarb 176-77, 231. Also militating for grand jury pro- 
Moreover, in light of the interpretive dilemmas generated by Mr. Justice Clark's retreat from a constitutional standard, reliance upon the Court's discretionary powers to effectuate this amalgamation would appear to be improvident. At the very least, because of the manifold and significant questions left unanswered by Cheff, future conflict and consequent reformulation of contempt procedures appear both inevitable and desirable. ${ }^{113}$

cedures in contempt cases is the fact that while the fifth amendment specifically excludes certain actions such as courts martial from indictment requirements, see United States ex rel. Toth v. Quarles, 350 U.S. 11 (1955), contempt proceedings are not excluded. By implication, their potential inclusion under the fifth amendment directive is without specific impediment.

The Supreme Court rejected the "infamous" nature of contempt, reasoning that the offense was distinguishable from the types of "crimes" which the constitutional framers contemplated. Green v. United States, supra at 183-85. Not only is this a questionable interpretation of history, see note 55 supra, but the decision also pre. ceded the Barnett-Cheff imposition of mandatory jury trials for contempts of a nonpetty nature. Thus, its precedential value produces no compelling conclusion as to the availability of grand jury indictments.

${ }^{113}$ If the Supreme Court desired to preserve a non-constitutional basis for its reformation of traditional contempt powers, any further alteration to achieve pro. cedural fairness could be made in the form of an amendment to FED. R. CRIM. P. 42. Such a change would be made pursuant to 18 U.S.C. $\$ 3771$ (1964): "The Supreme Court of the United States shall have the power to prescribe . . . rules of pleading, practice, and procedure ... in criminal cases and proceedings to punish for criminal contempt of court in the [federal courts] .... All laws in conflict with such rules shall be of no further force or effect after such rules have taken effect." (Emphasis added.) Choice of a rule amendment would not only render irrelevant any conflict with existing congressional intent but would also provide an opportunity for more specificity in the standards prescribed, for the revised rule could be formulated to cover all types of contempts and need not be limited to a consideration of the issues in a particularized judicial controversy. 